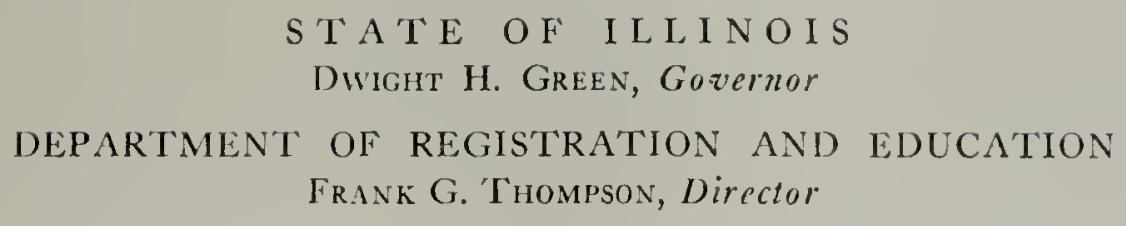

NATURAL HISTORY SURVEY DIVISION

Theodore H. Frison, Chief

\begin{tabular}{lll}
\hline Volume 23 & B ULLE T I N & Article 3 \\
\hline
\end{tabular}

\title{
Overfishing in a
}

\section{Small Artificial Lake}

\section{Onized Lake Near Alton, Illinois}

GEORGE W. BENNETT

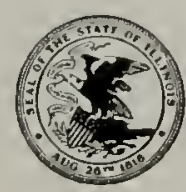

Printed by Authority of the State of Illinois

URBANA, ILLINOIS

May 1945 
S T A T E O F I L I I O I S

Dwight H. Green, Governor

DEPARTMENT OF REGISTRATION AND EDUCATION

Frank G. ThOMPSON, Director

BOARD OF NATURAL RESOURCES AND CONSERVATION

FrANK G. THOMPSON, Chairman

William Trelease, D.Sc., LL.D., Biolog $y^{*}$

Ezra J. Kraus, Ph.D., D.Sc., Forestry

L. R. Howson, B.S.C.E., C.E., Engineering
Arthur Cutts Willard, D.Eng., LL.D., President of the University of Illinois Norman L. Bowen, Ph.D., Geology

Roger Adams, Ph.D., D.Sc., Chemistry

\section{NATURAL HISTORY SURVEY DIVISION Urbana, Illinois}

Scientific and Technical StafF

Theodore H. Frison, Ph.D., Chief

FLORENCE A. NYBerg, Assistant to the Chief

Section of Economic Entomology

G. C. Decker, Ph.D., Entomologist

M. D. FARrar, Ph.D., Research Entomologist

J. H. Bigger, M.S., Associate Entomologist

S. C. Chander, B.S., Southern Ficld Entomologist

James W. Apple, M.S., Northern Field Entomologist

B. G. Berger, M.A., Assistant Entomologist

John M. Wright, B.A., Assistant Entomologist (on leave)

H. B. Petty, JR., M.A., Associate in Entomology Extension

C. J. Weinman, Ph.D., Special Research Assistant

Willis N. Bruce, B.S., Special Research Assistant

\section{Section of Insect Survey}

H. H. Ross, Ph.D., Systematic Entomologist

Carl O. MoHr, Ph.D., Associate Entomologist, Artist (on leave)

B. D. Burks, Ph.D., Assistant Entomologist (on leave)

Milton W. Sanderson, Ph.D., Assistant Entomologist

Kathry M. Sommerman, M.S., Artist, Entomological Assistant

Phyrlus A. BeAver, Laboratory Assistant

\section{Section of Forestry}

James E. Davis, M.F., Extension Forester

LeE E. Yeager, Ph.D., Forester

\section{Section of Aquatic Biology}

George W. Bennett, Ph.D., Limnologist

D. F. Hansen, Ph.D., Assistant Zoologist

Paul G. Barnickol, M.A., Ichthyologist

BRUNo von Limbach, M.S., Special Researc. Assistant

Section of Game Research and Management R. E. Yeatter, Ph.D., Game Specialist

Section of Wildlife Experimental Areas

Arthur S. Hawnins, M.S., Game Technicia. (on leave)

F. C. Bellrose, Jr., B.S., Assistant Game Technician

Harold C. Hanson, M.S., Assistant Game Teclinician

Section of Applied Botany and Plant Pathology

L. R. Tehon, Ph.D., Botanist

J. C. Carter, Ph.D., Assistant Botanist

G. H. BoEwe, M.S., Field Botanist

J. L. Forsberg, M.S., Rescarch Pathologist

Bessie B. Henderson, M.S., Research Assistant

\section{Section of Publications}

James S. Ayars, B.S., Technical Editor

ELEANOR G. WOLFF, B.Ed., Assistant Tech nical Editor

Technical Library

Marguerite Simmons, M.A., M.S., Technica Librarian

Consultants in Herpetology: Howard K. Gloyd, Ph.D., Director of the Museum, Chicagi Academy of Sciences; Clifford H. POPE, B.S., Curator of Amphibians and Reptiles, Chicagi Natural History Museum.

*Deceased January 1, 1945.

This paper is a contribution from the Section of Aquatic Biology. 


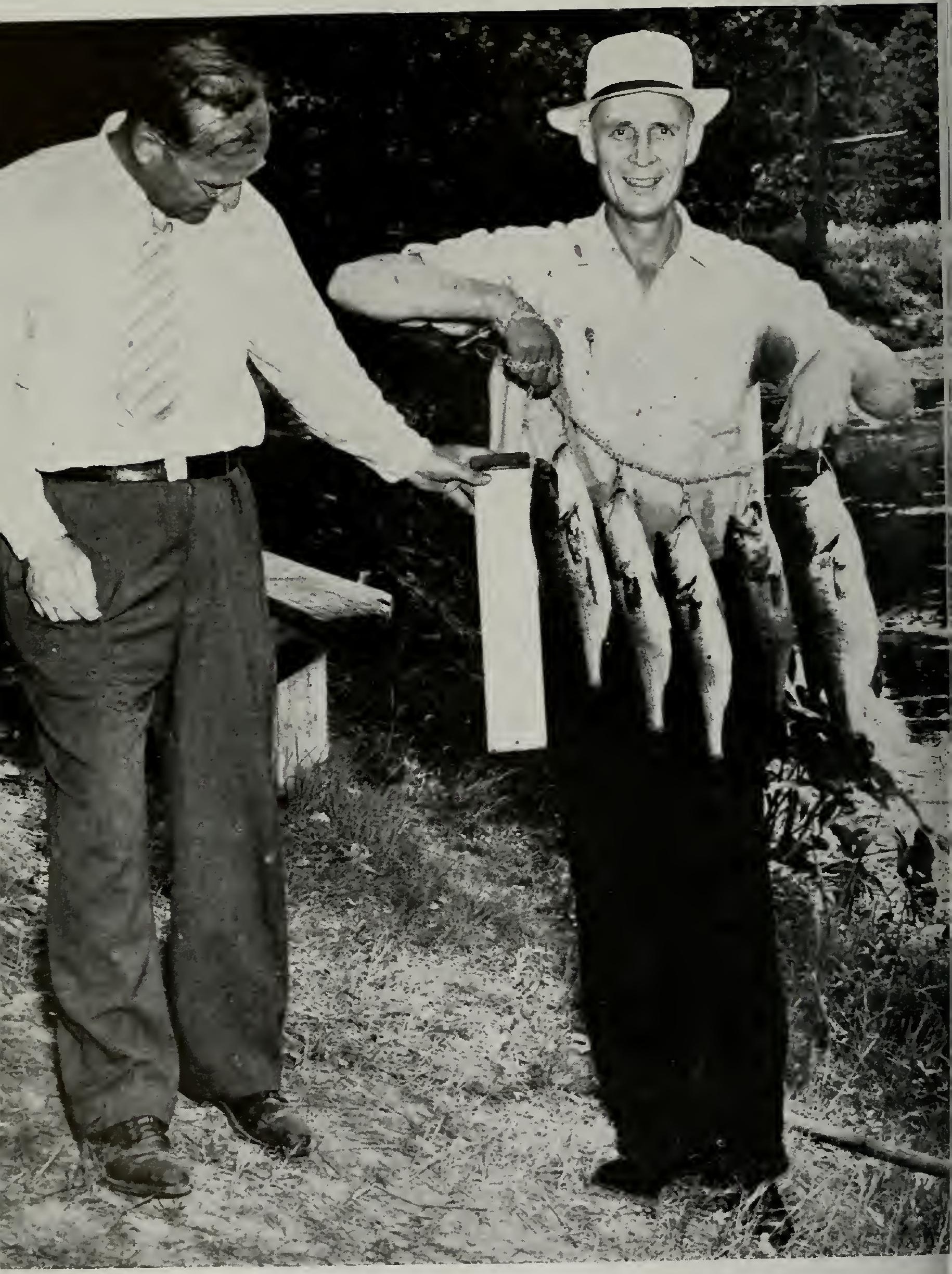

Some of the largemouth bass taken in th final census of Onized Lake in 1941. W. II Wood, inspecting fish, and Lyle Walker, hold ing them, are two of the several members c the Onized Club who assisted in the census. 


\section{Overfishing in a Small Artificial Lake}

\section{Onized Lake Near Alton, Illinois}

B

EFORE North America was extensively settled, native fish were the staple food for a wide variety of predatory mammals, birds and reptiles, as well as for adult game and other piscivorous fishes. With few exceptions, the natural predators captured small individuals of the various fish species in proportion to the relative abundance of such fish; as the larger individuals were less subject to attack than the smaller individuals, an accumulation of large fish resulted.
Under conditions involving extensive juvenile mortality, the survival of any species of fish depends upon a high reproductive potential, adjusted to compensate for large losses. Most species that exist today have a high reproductive potential. The species that produce comparatively few eggs have unusual behavior patterns that offer special protection to their spawn.

As the human communities have spread to cover the continent, native fishes have been subjected to a different kind of

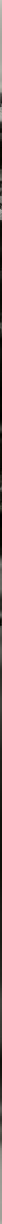

Onized Lake as seen when looking east from the spillway toward the lower end of the larger bay. The fairly steep banks surrounding the lake are well grassed except where worn by Iraffic. On the hill above the fishing pier, left, are brick grills, picnic tables and a shelter. 
attack. Man has become a selective predator of large fishes. He has waged continual warfare on other fish predators, has passed laws directed at controlling any inclination on his part to take small fish, and has developed an artificial propagation and stocking program to augment the supply of small fish. Because the high reproductive potential of the fishes has remained unchanged, there has been a great increase in the survival of young fish, resulting in added competition for food and space, in overpopulation of waters and in stunting of fish. Intensive interspecific competition among the fishes themselves may be the key factor responsible for eliminating or reducing populations of many of the more desirable game fishes in some waters, because the young of these species are unable to compete with the young of others under crowded conditions.

A common belief among anglers is that, in lakes in which the annual yield of game fish has declined over a period of years, intensive fishing is responsible for the progressively poorer catches. In most instances in which an actual decline may be proved, no data are at hand as to the kinds and quantities of fish that remain in the lake at the time of low production. However, in 22 artificial lakes in Illinois, most of which were censused at a time of low production, only one showed a decline in yield associated with intensive fishing. Whether intensive angling is or has been directly responsible for a reduction in game fish yields of other Illinois lakes, particularly those larger than 25 acres, is subject to question. The efficiency of angling devices is so low, and the patience of the average angler so short, that, long before the population of the selected species has been reduced to the danger point below which it cannot reproduce itself, the fishing for that species has become so uninteresting that it is greatly reduced, or it may even be stopped.

It is not uncommon for populations of desirable fish to become depleted in, or disappear from, waters that are fished very little. This occurrence is frequent in artificial lakes and reservoirs where predators of small fish are at a minimum. Here competition among those desirable species artificially introduced, along with competition from undesirable kinds that gain entrance through feeder streams, eventu- ally crowds out the more desirable species.

'The term "overfishing" as it relates to lakes is loosely used by anglers. By some it is applied to a process characterized by the depletion of a single select species, a depletion attributed to more or less intensive fishing (usually an unspecified number of man-hours) for that species. Actually this decrease in yield may result from competition with other fish wherein the select species is gradually replaced by another or several other species, less desirable to anglers. In such a case the water cannot be said to be overfished, for it supports a fish population at least as great in total weight as that when the select species was present in numbers.

In the strict sense, the term overfishing involves the entire fish population of a body of water. The yield taken by anglers is not restricted to one or a few species but includes all or almost all in near proportion to their relative abundance. 'This yield, considered in pounds of fish flesh, is removed at a rate faster than it can be replaced by conversion of available natural food into flesh, and the poundage of fish supported by the water remains below the carrying capacity of that water for all fish. Overfishing as defined here is a condition that is extremely rare because it requires a very great intensity of angling.

The only case of overfishing ever observed in Illinois by Natural History Survey aquatic biologists occurred under conditions favorable for study, 1938-1941. Evidence of overfishing was available from well-kept records of hook-and-line catches for two complete fishing seasons and parts of two others, and from sample catches made with test hoopnets in 1938 and 1940. In 1941 the lake was treated with a plant alkaloid to kill the fish, and a careful census of the fish population was made.

This investigation would have been impossible without the continual interest and cooperation of members of the Fish-, ing Club of the Owens-Illinois Glass Company of Alton, Illinois.

Overfishing in Onized Lake was the: result of an intensity of angling far greater than that observed in most waters. Only under conditions of heavy use of a small body of water by a club, community or industry, where fishing is associated with other forms of outdoor recreation, would this intensity of fishing be duplicated. 
the other extending north-northwest. Surface water entering the smaller arm drains from a cultivated field, and that running into the main arm drains from a pasture and barnlot, the latter located about 200 yards from the lake. The entire drainage area is not more than 15 or 20 acres.

The banks of the ravine in which Onized
Lake was built are relatively steep except toward the upper ends of the two arms, resulting in little shallow water along most of the shore line. Soundings indicate a maximum depth of 21 feet in the southwest part of the lake near the dam, and much of the lake is from 10 to 14 feet in depth. The average depth is approxi-

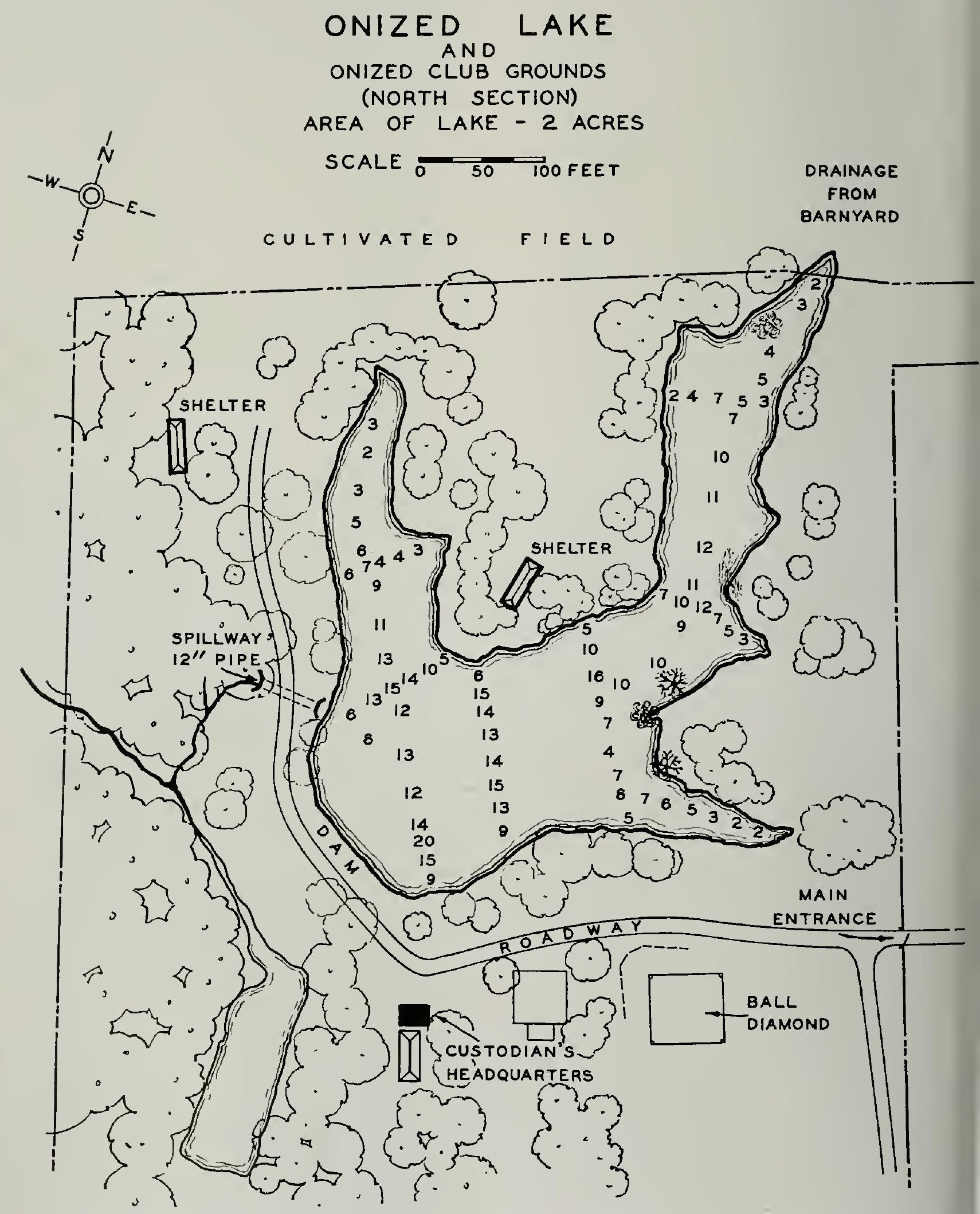

Fig. 1.-Map of Onized Lake and the north section of the recreation area used by the OwensIllinois Glass Company employees. Fishermen entering and leaving the lake are readily checked by the custodian at his headquarters. 
mately 8 feet. Although the drainage area is small, the water level rarely fluctuates more than 2 or 3 feet during the year. A 12 -inch tile serves adequately as a spillway.

The area immediately around the lake is used extensively for picnics. Large oaks are scattered over this area, and the shores are well grassed except where heavily shaded or worn by traffic.

Aquatic plants are cattails, Typha latifolia L.; pickerelweed, Pontederia cordata L.; arrowhead, Sagittaria spp.;

Table 1.-Vertical series of temperatures and oxygen samples from Onized Lake during very hot weather, 10:00 A.M., August 29, 1938.

\begin{tabular}{|c|c|c|c|}
\hline $\begin{array}{l}\text { DEPTH, } \\
\text { FEET }\end{array}$ & & $\begin{array}{c}\text { Temperature, } \\
\text { DegreEs F. }\end{array}$ & $\begin{array}{l}\text { Dissolved } \\
\text { Oxygen, } \\
\text { Parts Per } \\
\text { Million }\end{array}$ \\
\hline Surface & & 78.0 & 6.0 \\
\hline 1 & $\ldots$ & 78.0 & 5.4 \\
\hline 3 & $\ldots \ldots$ & 75.1 & 3.0 \\
\hline 5 & $\ldots$ & 74.2 & 0.0 \\
\hline 7 & $\ldots \ldots$ & 71.8 & 0.0 \\
\hline 9 & & 67.3 & 0.0 \\
\hline 11 & $\ldots \ldots$ & 63.5 & 0.0 \\
\hline 13 & & 59.0 & 0.0 \\
\hline 15 & . & 58.0 & 0.0 \\
\hline 17 & $\ldots$ & 55.4 & 0.0 \\
\hline 19 & $\ldots \ldots$ & 55.4 & 0.0 \\
\hline 21 & $\ldots \ldots$ & 54.7 & 0.0 \\
\hline
\end{tabular}

American lotus, Nelumbo pentapetali (Walt.) Fern., * planted pond lilies of unknown species; coontail, Ceratophyllum demersum L. ; elodea or waterweed, Anacharis canadensis (Michx.) Planch.; and creeping water primrose, Jussiaea diffusa Forsk. These plants have encroached upon all of the limited shallow water area.

In many respects, Onized Lake is typical of small deep ponds that are protected from wind action. The waters of these ponds become thermally stratified late in spring and remain so until late fall. Sufficient organic matter is present to produce a high oxygen demand, with the result that throughout most of the summer little or no oxygen is present at depths below 3 or 4 feet.

A series of oxygen samples and temper-

${ }^{*}$ Nelumbo littea (Willd.) Pers. of some manuals.
Table 2.-Mineral analysis of a sample of water from Onized Lake, collected from the lake surface near the dam on August 31, 1938. Analysis made by J. B. Swartz of the State Water Survey Division.

\begin{tabular}{|c|c|c|}
\hline AnAlysis & & $\begin{array}{c}\text { Parts Per } \\
\text { Million }\end{array}$ \\
\hline Iron (total). & $\mathrm{Fe}$ & 0.6 \\
\hline Silica .............. & $\mathrm{SiO}_{2}$ & 8.0 \\
\hline Calcium............. & $\mathrm{Ca}$ & 18.0 \\
\hline Magnesium........... & $\mathrm{Mg}$ & 11.2 \\
\hline Ammonium ............ & $\mathrm{NH}_{4}$ & 1.7 \\
\hline Sodium and potassium. & $\mathrm{Na}, \mathrm{K}$ & 2.5 \\
\hline Sulfate.............. & $\mathrm{SO}_{4}$ & 11.9 \\
\hline Nitrate............. & $\mathrm{NO}_{3}$ & 1.8 \\
\hline Chloride. . . . . . . . . . & $\mathrm{Cl}$ & 8.0 \\
\hline Methyl orange alkalinity & & 76.0 \\
\hline Total hardness......... & & 91.5 \\
\hline
\end{tabular}

atures was taken in Onized Lake, August 29,1938 , during a period of very hot weather. These temperatures and oxygen analyses, given in table 1 , are probably representative of extreme summer conditions.

Water samples showed little oxygen at 3 feet and none at a depth of 5 feet and below. The surface water was warm (78 degrees F.) but at 3 feet the temperature had dropped almost 3 degrees $F$, and at depths of 5 to 17 feet the samples taken at 2-foot intervals showed drops of 1 degree to more than 4 degrees per interval. Throughout the three greatest depths, 17, 19 and 21 feet, the temperature changed very little.

There is evidence that drainage from the barn lot entering the main arm of the lake adds materially to the fertility of the water, but produces some conditions that are undesirable from a recreational standpoint. Heavy rains in late spring and early summer are frequently followed by a bloom of subsurface algae, or by the appearance of numerous patches of floating bluegreens (Oscillatoria). A large yearly crop of bullfrog tadpoles, Rana catesbeiana Shaw, is produced in the lake. These die in large numbers during periods of water bloom, presumably from eating partially decayed bluegreen algae. The appearance and odor, at these times, of putrifying tadpoles and algae are obnoxious to the public. Efforts to control algae by hauling out the floating mats and by 
applying copper sulfate have been only partially satisfactory.

A sample of water collected from the lake was analyzed by the State Water Survey, table 2. The presence of 1.7 parts per million of ammonium indicates pollution from barnyard waste. Other parts of this analysis, as compared with similar analyses from many other Illinois ponds, show that the water of Onized Lake is somewhat softer than that of most other ponds.

Further indications of pollution from the barn lot came to light in hoopnet fishing operations in the terminal portion of the main arm in the summers of 1938 and 1940. Most of the fish caught in hoopnets set in the shallow water of this arm, and left overnight, died, while those caught in other parts of the lake, and similarly treated, lived.

No loss of fish has been observed in Onized Lake outside of nets, and it is probable that fish move out of the upper end of the larger arm or bay when periods of oxygen reduction occur. Undoubtedly, the waste from the barnyard has stimulated the growth of fish food organisms and, hence, the fish production of the lake.

\section{Evidences of Overfishing}

Onized Lake was stocked with 10,000 fingerling fish in 1934, from the state hatchery near Lebanon. No record is available of the kinds of fish used, but it is believed that largemouth bass and crappies predominated in this group. The next year, 1935, 2,000 fish, species unknown, from the Lebanon hatchery, were placed in Onized Lake, when it was found that the water level in a pond near Brighton, for which they had been intended, was dangerously low. Fishing in Onized Lake was begun in 1937 and it is probable that at that time, with 12,000 fish that had been stocked plus their young of 1935, 1936 and 1937, the lake was overpopulated and the fish already stunted.

L. H. Nicolet of the Owens-Illinois Glass Company estimates that over a 5year period an average of 125 families fished the lake each year. Fishing permits were issued to about 100 families in 1939 , and to a few less in 1940 and 1941. In addition, approximately 95 special passes were issued each year.
Near the end of the fishing season of 1938, the Natural History Survey furnished the Onized Lake caretaker with a creel census record book in which records could be made for each fishing trip, including the date, name of fisherman, number of hours of fishing, kinds of fish caught, numbers caught and their total weight. Mr. Conrad, in charge of the grounds, was much interested in the returns from fishing and checked each fisherman on entering and leaving the area. Fishing was heaviest on week-ends, beginning on Friday and usually reaching a peak on Sunday. Few fishermen appeared on Monday. As the custodian was on duty over the week-end, he was allowed a free day on Tuesday. Although some Tuesday fishermen were interested enough in keeping records to inform Mr. Conrad of catches made on that day, others did not take the trouble to do so; therefore, the Tuesday record is not complete. No attempt has been made to estimate either the total Tuesday catch or the fishing intensity for that day, so that figures listed in the tables dealing with catch and fishing intensity are somewhat lower than if this information could have been included.

The evidence for overfishing originates from three sources: (1) a creel census; (2) hoopnet samples of the population and (3) comparison of the poisoned fish population of June, 1941, with figures from the creel census and the hoopnet sampling.

The first and probably the best evidence of overfishing in Onized Lake is from the creel census. A comparison of the total weight of fish taken by anglers during the fishing seasons of 1939 and 1940, table 3, indicates that a considerable drop in yield occurred in the latter year, after nearly 700 pounds of fish had been removed from Onized Lake in 1939. Apparently the 1939 catch was greater in pounds than could be replaced by the assimilation of the natural food supply. The fact that about 1,000 fewer fish were caught in 1940 than in 1939 does not necessarily mean that the actual number of fish present in the lake had been reduced. No figures are available on the abundance of natural spawn, but a.few successful individual broods could easily have replaced the numbers taken. It rather suggests that the number of fish of desirable sizes 
Table 3.-Statistics on anglers' catch of fish from Onized Lake, 1938-1941.

\begin{tabular}{|c|c|c|c|c|c|c|}
\hline Date & $\begin{array}{c}\text { Number of } \\
\text { Man-Hours } \\
\text { of Fishing }\end{array}$ & $\begin{array}{c}\text { Number of } \\
\text { Fish } \\
\text { CaUght }\end{array}$ & $\begin{array}{l}\text { Total } \\
\text { Weight } \\
\text { of Fish, } \\
\text { Pounds }\end{array}$ & $\begin{array}{l}\text { Average } \\
\text { WeIght } \\
\text { of Fish, } \\
\text { Pounds }\end{array}$ & $\begin{array}{c}\text { Number of } \\
\text { Fish Per } \\
\text { Man-Hour }\end{array}$ & $\begin{array}{c}\text { Pounds of } \\
\text { Fish Per } \\
\text { Man-Hour }\end{array}$ \\
\hline \multicolumn{7}{|l|}{1938} \\
\hline September... & 117.00 & 23 & 21.50 & 0.93 & 0.197 & 0.184 \\
\hline October..... & 17.75 & 5 & 4.25 & 0.85 & 0.282 & 0.239 \\
\hline Season...... & $1.3+.75$ & 28 & 25.75 & 0.92 & 0.208 & 0.191 \\
\hline \multicolumn{7}{|l|}{1939} \\
\hline April....... . & 163.25 & 147 & 51.38 & 0.35 & 0.900 & 0.315 \\
\hline May........ & 717.50 & 834 & 259.72 & 0.31 & 1.162 & 0.362 \\
\hline June....... & 847.25 & 793 & 246.56 & 0.31 & 0.936 & 0.291 \\
\hline July . . . . . . & 602.50 & 299 & 79.75 & 0.27 & 0.496 & 0.132 \\
\hline August. ... . . & 251.00 & 40 & 24.00 & 0.60 & 0.159 & 0.096 \\
\hline September... & 135.25 & 14 & 27.00 & 1.93 & 0.104 & 0.200 \\
\hline October..... & 113.00 & 33 & 11.50 & 0.35 & 0.292 & 0.102 \\
\hline Season..... & $2,829.75$ & 2,160 & 699.91 & 0.32 & 0.763 & 0.247 \\
\hline \multicolumn{7}{|l|}{$19+0$} \\
\hline April....... & 30.50 & 25 & 7.60 & 0.30 & 0.820 & 0.249 \\
\hline May........ & 995.80 & 370 & 93.75 & 0.25 & 0.372 & 0.094 \\
\hline June........ & 947.20 & 290 & 76.15 & 0.26 & 0.306 & 0.080 \\
\hline July . . . . . . & 459.00 & 89 & 20.83 & 0.23 & 0.194 & 0.045 \\
\hline August. . . . . & 484.00 & 328 & 66.44 & 0.20 & 0.678 & 0.137 \\
\hline September... & 343.00 & 71 & 17.26 & 0.24 & 0.207 & 0.050 \\
\hline October.... & 35.00 & 2 & 3.00 & 1.50 & 0.057 & 0.086 \\
\hline Season...... & $3,294.50$ & 1,175 & 285.03 & $0.2 t$ & 0.357 & 0.086 \\
\hline \multicolumn{7}{|l|}{1941} \\
\hline April....... & 267.30 & 143 & 40.75 & 0.28 & 0.535 & 0.152 \\
\hline May. & 652.70 & 255 & 63.24 & 0.25 & 0.391 & 0.097 \\
\hline June. & 347.90 & 236 & 37.75 & 0.16 & 0.678 & 0.108 \\
\hline Season...... & $1,267.90$ & 634 & 141.74 & 0.22 & 0.500 & 0.112 \\
\hline Grand total. . & $7,526.90$ & 3,997 & $1,152.43$ & Grand average & 0.531 & 0.153 \\
\hline
\end{tabular}

was smaller and that the new broods of young were unable to grow fast enough to reach the size range of interest to anglers. No accurate records were made of the number of small fish returned to the lake by fishermen, but verbal information obtained from persons familiar with the situation suggests that in 1940 many more fish were returned than were taken. Table 3 shows also that the average weight of fish taken in 1940 was considerably less than that in 1939. The fishing intensity actually increased in $19+0$ over that of 1939 by about 16 per cent.

In both 1939 and 1940, more fish were caught in May and June than during other months, with the exception of August of $19+0$; also, the fishing intensity was greater in May and June than at other times.

The catch per man-hour was highest during May of 1939 when 1.162 fish were taken per hour of effort. June of 1939 was also a productive month, although the rate dropped to 0.936 fish per man-hour. The unusual August rate of catch in 1940

Table 4.-Hook-and-line yield and fishing intensity per acre of water in Onized Lake, area 2 acres, 1938,* 1939, 1940 and $1941 . \dagger$

\begin{tabular}{|c|c|c|c|}
\hline YEAR & $\begin{array}{c}\text { Number of } \\
\text { of Fish } \\
\text { Caught }\end{array}$ & $\begin{array}{l}\text { WEIGHT } \\
\text { of Fish, } \\
\text { Pounds }\end{array}$ & $\begin{array}{c}\text { MAN-Hours } \\
\text { OF } \\
\text { FISHING }\end{array}$ \\
\hline $1938^{*}$ & 14 & 12.88 & 67.4 \\
\hline $1939 \ldots \ldots$ & 1,080 & 349.95 & $1,414.9$ \\
\hline $1940 \ldots \ldots$ & 558 & 142.52 & $1,647.2$ \\
\hline $1941 \dagger \ldots \ldots$ & 317 & 70.87 & 634.0 \\
\hline
\end{tabular}

* Only September and October in this year.

tOnly April, May and June in this year. 
of 0.678 fish per man-hour was due to abnormal success in angling for bluegills. The average catch for the period covered by the census was 0.531 fish per man-hour.

Throughout the creel census period there was a gradual reduction in the average weight of fish caught; average weights were 0.92 pound in $1938 ; 0.32$ in 1939 ; 0.24 in 1940 and 0.22 in 1941. Abnormally high average weights may be observed for September and October of 1938, August and September of 1939, and October of 1940 . These were due to the influence of proportionally larger catches of largemouth bass, a fish that averaged heavier than other species.

As a brief summary of fishing at Onized Lake it may be stated that, during the period of study, this 2-acre lake produced a hook-and-line yield of 3,997 fish, weighing $1,152.43$ pounds, requiring fishermen to expend 7,526.9 man-hours in return for an average catch of 0.531 fish per manhour, table 3.

Statistics on fishing intensity and yield from widely scattered investigations are

Table 5.-Analysis of the hook-and-line catch by species, Onized Lake, 1938,* 1939, 1940 and $1941 . \dagger$

\begin{tabular}{|c|c|c|c|c|c|c|c|c|c|c|}
\hline YEAR & Statistics & 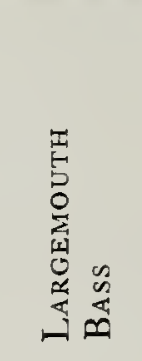 & 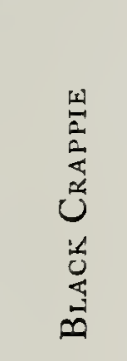 & 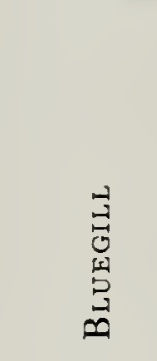 & 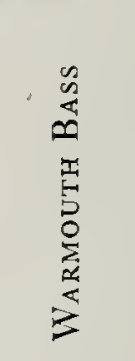 & 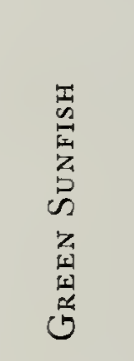 & 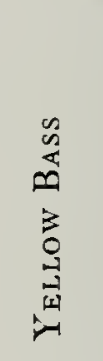 & 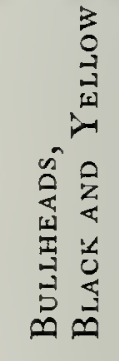 & 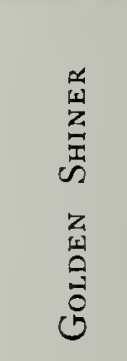 & $\vec{E}$ \\
\hline \multirow{3}{*}{$1938^{*}$} & \multirow{3}{*}{$\begin{array}{l}\text { Number........ } \\
\text { Total weight, } \\
\text { pounds....... } \\
\text { Average weight, } \\
\text { pounds....... }\end{array}$} & 13 & 3 & 3 & 3 & 2 & & 4 & & 28 \\
\hline & & 19.25 & 0.75 & 1.00 & 0.75 & 0.50 & & 3.50 & & 25.75 \\
\hline & & 1.48 & 0.25 & 0.33 & 0.25 & 0.25 & & 0.88 & & \\
\hline \multirow{3}{*}{1939} & Number & 62 & 502 & 1,393 & 14 & 137 & 4 & 48 & & 2,160 \\
\hline & pounds...... & 106.31 & 181.19 & 347.21 & 5.05 & 24.90 & 2.75 & 32.50 & & 699.91 \\
\hline & $\begin{array}{l}\text { Average weignt, } \\
\text { pounds....... }\end{array}$ & 1.71 & 0.36 & 0.25 & 0.36 & 0.18 & 0.69 & 0.68 & & \\
\hline \multirow{3}{*}{1940} & Number. . & 29 & 56 & 639 & 54 & 358 & 3 & 23 & 13 & 1,175 \\
\hline & $\begin{array}{l}\text { pounds....... } \\
\text { Average weight }\end{array}$ & 39.78 & 22.45 & 131.85 & 15.81 & 55.07 & 2.50 & 15.12 & 2.45 & 285.50 \\
\hline & pounds....... & 1.37 & 0.40 & 0.21 & 0.29 & 0.15 & 0.83 & 0.66 & 0.19 & \\
\hline \multirow{3}{*}{$1941 \dagger$} & $\begin{array}{l}\text { Number.......... } \\
\text { Total weight, }\end{array}$ & 0 & 31 & 398 & 34 & 122 & & 14 & 27 & 634 \\
\hline & $\begin{array}{l}\text { pounds....... } \\
\text { Average weight }\end{array}$ & 13.74 & 10.25 & 73.75 & 11.75 & 14.75 & & 12.25 & 5.25 & 141.74 \\
\hline & Nove & 1.72 & 0.33 & 0.18 & 0.34 & 0.12 & & 0.88 & 0.19 & \\
\hline \multirow{5}{*}{$\begin{array}{l}\text { All } \\
\text { Years }\end{array}$} & Total number. & 112 & 592 & 2,433 & 105 & 619 & 7 & 89 & 40 & 3,997 \\
\hline & $\begin{array}{c}\text { pounds......... } \\
\text { Average weight. }\end{array}$ & 179.08 & 214.64 & 553.81 & 33.36 & 95.22 & 5.25 & 63.37 & 7.70 & $1,152.43$ \\
\hline & & 1.60 & 0.36 & 0.23 & 0.32 & 0.15 & 0.75 & 0.71 & 0.19 & \\
\hline & $\begin{array}{l}\text { Per Cent of } \\
\text { Total Number. }\end{array}$ & 2.8 & 14.8 & 60.9 & 2.6 & 15.5 & 0.2 & 2.2 & 1.0 & 100.0 \\
\hline & $\begin{array}{l}\text { Per Cent of } \\
\text { Total Weight. }\end{array}$ & 15.5 & 18.6 & 48.1 & 2.9 & 8.3 & 0.5 & 5.5 & 0.6 & 100.0 \\
\hline
\end{tabular}


Table 6.-Hoopnet catches of fish from Onized Lake, August 28-30, 1938 (9 net-days of fishing), and July 10-15, 1940 (36 net-days of fishing).

\begin{tabular}{|c|c|c|c|c|}
\hline Species & Number & $\begin{array}{c}\text { Total } \\
\text { Weight, } \\
\text { Pounds }\end{array}$ & $\begin{array}{c}\text { Number of } \\
\text { Fish PER } \\
\text { Net-Day }\end{array}$ & $\begin{array}{c}\text { Weight of } \\
\text { Fish Per } \\
\text { Net-Day, } \\
\text { Pounds }\end{array}$ \\
\hline \multicolumn{5}{|l|}{ 1938-9 Net-Days of Fishing } \\
\hline Largemouth bass.......... & 8 & 12.37 & 0.89 & 1.37 \\
\hline Black crappie............. & 214 & 50.60 & 23.78 & 5.62 \\
\hline Bluegill. . . . . . . . . . . . & 54 & 15.24 & 6.00 & 1.69 \\
\hline Warmouth bass.......... & 5 & 1.15 & 0.56 & 0.13 \\
\hline Green sunfish........... & 2 & 0.32 & 0.22 & 0.04 \\
\hline 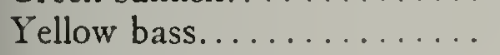 & 2 & 1.40 & 0.22 & 0.16 \\
\hline Black bullhead............ & 1 & 1.90 & 0.11 & 0.21 \\
\hline Yellow bullhead. .......... & 9 & 3.10 & 1.00 & 0.34 \\
\hline Golden shiner............ & $\ldots$ & $\ldots$ & $\ldots$ & $\ldots$ \\
\hline Total.................. & 295 & 86.08 & 32.78 & 9.56 \\
\hline \multicolumn{5}{|l|}{ 1940-36 Net-Days of Fishing } \\
\hline Largemouth bass.......... & 1 & 3.15 & 0.03 & 0.09 \\
\hline Black crappie............ & 234 & 43.27 & 6.50 & 1.20 \\
\hline Bluegill . . . . . . . . . . . . . & 99 & 17.02 & 2.75 & 0.47 \\
\hline Warmouth bass ............ & 5 & 1.00 & 0.14 & 0.03 \\
\hline Green sunfish ........... & 1 & 0.07 & 0.03 & $\ldots$ \\
\hline Yellow bass.............. & 1 & 0.09 & 0.03 & $\ldots$ \\
\hline Black bullhead........... & 1 & 2.05 & 0.03 & 0.06 \\
\hline Yellow bullhead. .......... & $\ldots$ & $\ldots$ & $\ldots$ & $\ldots$ \\
\hline Golden shiner. . . . . . . . . & 8 & 1.57 & 0.22 & 0.04 \\
\hline 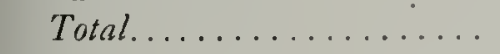 & 350 & 68.28 & $9.7 \%$ & 1.89 \\
\hline
\end{tabular}

most easily compared if all data are based upon a common unit; in this case, an acre of lake surface. For this reason table 4 has been introduced, giving the total numbers and weights of the fish caught and the fishing intensity in terms of man-hours, all on the basis of an acre of water surface. The yield per acre in $1939,349.95$ pounds, is higher than that recorded for any single year of hook-and-line fishing in any other artificial lake in the United States.

'The anglers' catch from Onized Lake presents several points of interest when broken down by species. This catch was composed of nine species of fish but only three, the largemouth bass, black crappie and bluegill, made up more than 10 per cent each of the total catch by weight. Table 5 lists the hook-and-line yield by species for the years included in the creel census, and also gives the totals and the percentages, for each species, of the total number and weight. Further reference to this table will be found in a later section, where individual species of fish are considered from the standpoint of numbers, growth and age-length distribution.
The second source of evidence for overfishing is from the total numbers and total weights of fish caught in hoopnets during a short period in 1938 and a somewhat longer period in 1940. A comparison of the catch per net-day of fishing for the two seasons gives indication of a reduced population of fish of desirable sizes in 1940.

Hoopnets were fished in Onized Lake, August 28 to 30, inclusive, in 1938 and July 10 to 15 , inclusive, in 1940 . In the 1938 fishing period, three 1 -inch mesh hoopnets were used with leads 40 to 50 feet in length. In the $19+0$ period, six 1 -inch mesh hoopnets were used with leads of essentially the same length as in 1938. Fish caught in each year were measured, weighed and returned to the lake, after a few scales had heen removed for age determination. In 1938, 10 crappies and 7 bluegills died in a net set for 24 hours in the upper end of the larger bay. In 1940, 13 crappies and 9 bluegills died in the same location. All other fish were in good condition when released. Twelve bluegills from the $19+0$ catch were trans- 
ported to a breeding pond below the lake dam.

The hoopnet catches for the two seasons are shown in table 6 . Although the total catch in number of fish was larger in 1940 than in 1938, the total weight of the catch was less; the number per net-day was 3.37 times as great in 1938 as in 1940 . Only two species of fish, black crappies and bluegills, were numerous enough in these catches for comparison. Both of these species readily enter the nets. In 1938, crappies were caught at the rate of 23.78 per net-day, while in 1940 the catch was
The evidence of a reduced population of fish of desirable sizes in 1940 is not as strong from a comparison of the rate of catch of hoopnets, as from the anglers' records, but both census methods indicate a striking reduction in the numbers of these fish.

\section{Analysis of the Population}

On June 24, after Onized Lake had been fished for 3 months in the 1941 season, the fish remaining in the lake were poisoned with the object of making a

Table 7.-Census of all fish in Onized Lake, area 2 acres, June 24-28, 1941.

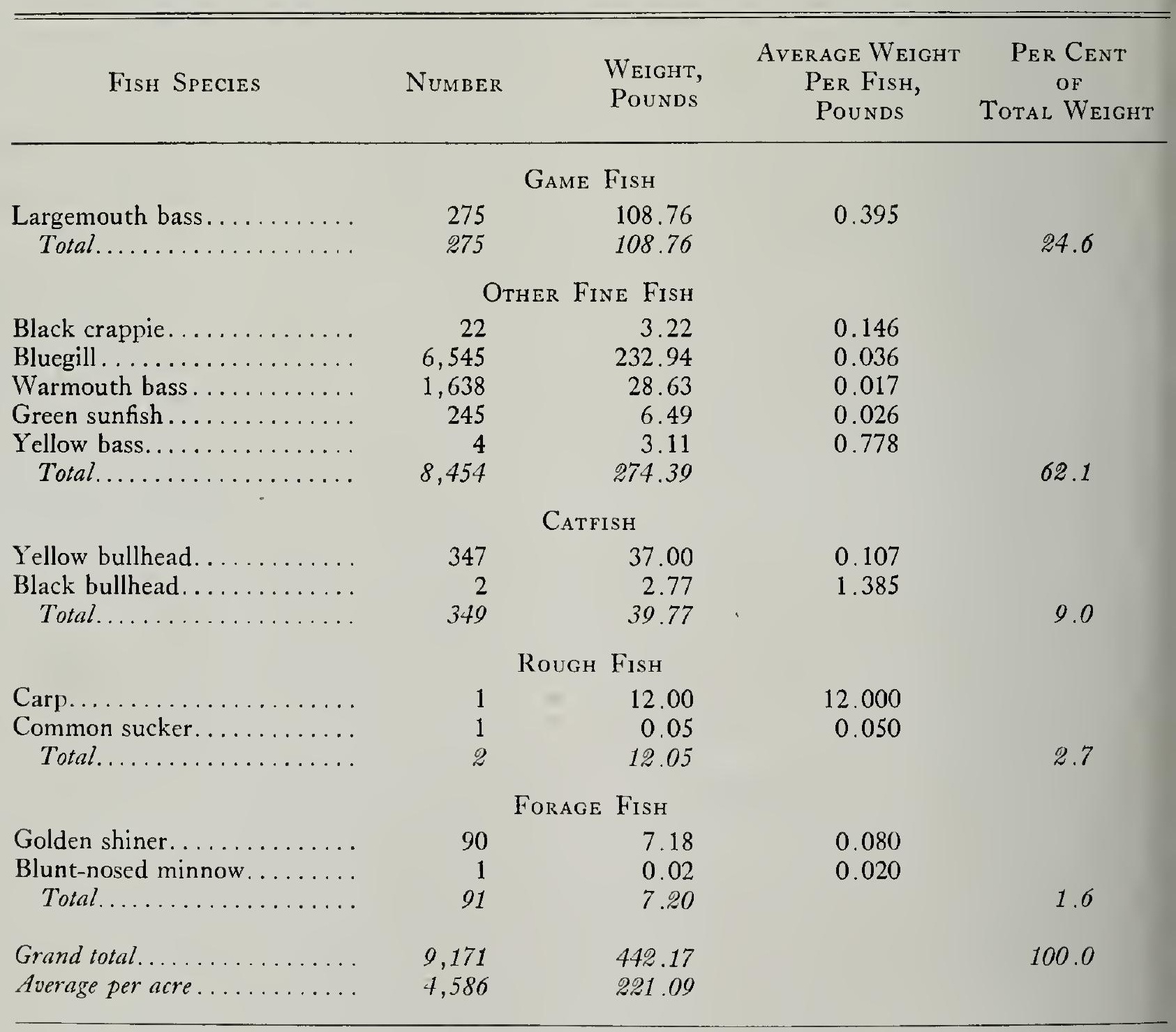

only 6.50 per net-day. In blue-gills the reduction in numbers was not so marked, as the 1938 catch was at the rate of 6.00 per net-day and the 1940 catch 2.75 per net-day. The reduction in weights of these two species from 1938 to 1940 , as shown by the catch per net-day, was even greater than the reduction in numbers. detailed study of a population supposedly depleted by overfishing. This study was designed to give answers to a number of questions; namely, (1) the weight of fish present in the lake, in pounds per acre, after the removal of a 1939 crop of 349.95 pounds per acre and a 1940 crop of 142.52 pounds per acre; (2) the actual and rela- 
Table 9.-Number of fish used in a study of the growth of Onized Lake fish.

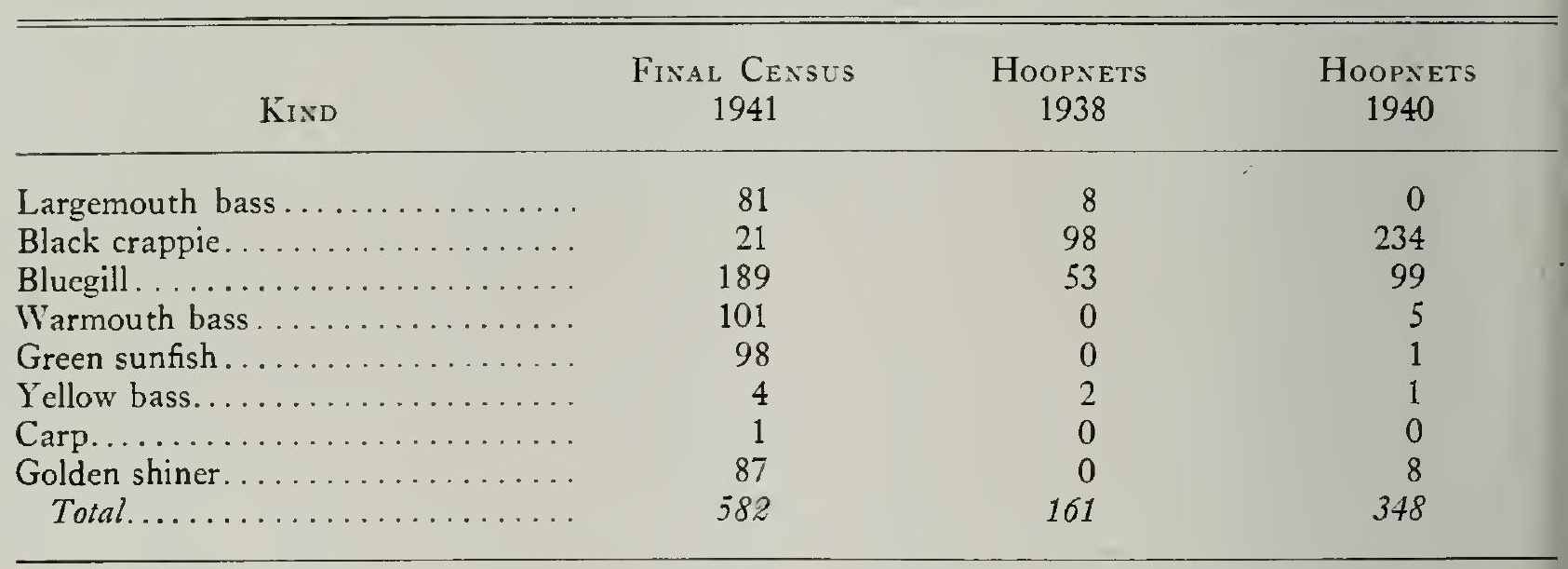

mutilated or decayed were discarded. Most of the larger fish were measured and "scaled," and random samples were taken from among the other, more numerous individuals of all species, so that the scale collections are believed to represent fairly all broods of all species then present. In this, as in other scale collections, the scales from a small number of fish had to be discarded, because all these scales were regenerate, or the age determinations were uncertain. The fish that were used in this study are listed in table 9.

A monograph on the growth of an individual species of fish should show the relationship between the growth increments of body (length) and the growth increments of a selected scale measured in a designated manner, in order to expose any disproportionate growth increments of scales that may require correction of body lengths calculated from scale measurements. This time-consuming process is hardly applicable to gross population studies involving many kinds of fish, particularly where the fish are killed with poi- son and must be handled in the least possible time to prevent loss from spoilage. All calculated lengths given in this study are direct proportions based upon measurement of the anterior radius of the scale and the total length of fish. Even though errors are introduced through this method, they are probably of small magnitude, and calculated lengths of fish from various waters, when handled in this way, are believed to be comparable.

Tables showing the age-length frequencies for each of the more abundant kinds of fish in Onized Lake at the time of the poison census are included with the following discussion. As the actual ages were determined on random samples. rather than on all fish, a description of the procedure is given below. When the poisoned population was handled, fish of legal lengths (bass) or of desirable sizes (other species) were carefully separated from the more numerous smaller individuals. Because of the relatively small numbers of large individuals, scales were taken from a high percentage of them. Scales were

Table 10.-Fish recovered from Onized Lake in the final census, June 24-28, 1941, and groupings used in the construction of age-length frequency tables.

\begin{tabular}{|c|c|c|c|c|}
\hline Species & $\begin{array}{c}\text { (1) } \\
\text { FisH MEASURED } \\
\text { AND AGED }\end{array}$ & $\begin{array}{c}(2) \\
\text { Fish MEAsUred } \\
\text { BUt Not AgED }\end{array}$ & $\begin{array}{c}(3) \\
\text { Fish Not Aged } \\
\text { OR MEASURED }\end{array}$ & TotaL \\
\hline $\begin{array}{l}\text { Largemouth bass..... } \\
\text { Black crappie...... }\end{array}$ & $\begin{array}{l}81 \\
21\end{array}$ & $\begin{array}{r}194 \\
1\end{array}$ & $\begin{array}{l}0 \\
0\end{array}$ & $\begin{array}{r}275 \\
22\end{array}$ \\
\hline Bluegill............. & 189 & 254 & $\left\{\begin{array}{c}5,877 \text { from } 3.0 \text { to } 5.7 \text { inches } \\
235 \text { from } 5.8 \text { to } 7.5 \text { inches }\end{array}\right\}$ & 6,545 \\
\hline $\begin{array}{l}\text { Warmouth bass...... } \\
\text { Green sunfish....... } \\
\text { Yellow bullhead..... } \\
\text { Golden shiner....... }\end{array}$ & $\begin{array}{r}101 \\
98 \\
0 \\
87\end{array}$ & $\begin{array}{r}114 \\
32 \\
89 \\
3\end{array}$ & $\begin{array}{c}1,423 \text { from } 2.0 \text { to } 5.7 \text { inches } \\
115 \text { less than } 5.7 \text { inches } \\
258 \text { from } 4 \text { to } 7 \text { inches } \\
0\end{array}$ & $\begin{array}{r}1,638 \\
245 \\
347 \\
90\end{array}$ \\
\hline
\end{tabular}


taken from a random sample of smaller fish measured individually, and individual length measurements were taken on many more fish. Finally, if a large number of a given kind of fish still remained after these samples were taken, they were sorted to size, weighed collectively and counted. Thus, the age-length frequency tables are based on data derived from (1) 577 fish, measured individually, the ages of which were determined from scales; (2) an additional number of fish, also measured individually, sorted into age groups on the basis of measured lengths; and finally (3) unaged fish, unmeasured individually but of known length range, sorted into age groups on the basis of age-length relationships. Table 10 lists the numbers of the various kinds of fish in each of the above groups.

The status of the population of each species of fish present in Onized Lake at the time of the final census was influenced by fishing pressure and by the ability of that species to reproduce successfully, as well as to compete with other species of fish. In the following discussion, individual species of fish are considered separately in an attempt to integrate the information furnished by the creel census, hoopnet sampling, the final census, age determinations and growth rates.

\section{Largemouth Bass}

Huro salmoides (Lacépède)

The largemouth bass population' at Onized Lake was, at the time of the final census in 1941, one of the best observed in 22 artificial lakes in Illinois (Bennett $19+3$ ), not only from the standpoint of number and weight per acre of lake surface, but also with reference to rates of growth and range of sizes. This population contained individuals belonging to six annual broods (one brood spawned each season, 1936-19+1), and the lengths of fish recovered ranged from $11 / 2$ to 22 inches. Fortyseven bass, or 17.1 per cent of the 275 present, were of legal lengths, tables 7 and 8 ; Onized Lake contained over 23 legalsized bass per acre in spite of very heavy fishing from 1939 through part of $19+1$. The greatest catch of bass occurred in 1939 when 62 individuals of legal sizes were taken, table $5 ; 29$ were taken in the season of 1940 and 8 in 1941 from May
15 to June 24 . 'These, and 13 others taken in September and October of 1938, make a total of 112 captured during the period of the creel census. While the hookand-line catch of largemouth bass made up only 2.8 per cent of the total number of fish removed by anglers, their combined weight was 179.1 pounds, or 15.5 per cent of the weight of all fish caught, table 5. Possibly all of the legal-sized bass in Onized Lake had become "educated" to avoid both artificial and natural baits offered by fishermen. The lake is so small that an experienced bait caster may cover the entire water area from the shore in about an hour. The fact that the lake still contained 47 bass of legal sizes in $19+1$, including 12 fish that ranged from 3 to 6 pounds in weight, suggests that factors other than angling may be responsible for low populations of bass in many Illinois waters less intensively fished.

The lengths and ages of the bass collected from Onized Lake are shown in table 11. The smallness of the number of hass in the 0 group (spawned in May, $19+1$ ) is due partially to predation at the time of poisoning. Small fish are affected by the treatment first, and all carnivorous fish of larger sizes quickly feed upon them, as they are readily captured at this time. Also, many small fish sink to the bottom of the lake as they die and are eaten or torn to pieces by crayfish and turtles. A fish census made by the poisoning method is inaccurate in the numbers of small fish of all kinds.

The natural spawn and survival of young bass in Onized Lake is considered to have been adequate to maintain the population of this fish at a high level-much higher than is usual in artificial lakes containing several species of fish (Bennett 19+3). As largemouth bass are known to spawn successfully in mud-bottomed ponds, it seems likely that low populations in many lakes are the result of loss of eggs through silting, through the roiling of waters by fish (bullheads, carp and other bottom feeders), or through the nest raiding activities of sunfish and other species when they are overly abundant (Swingle \& Smith 1943).

The growth rate of largemouth bass in Onized Lake was faster than in most Illinois waters. Average calculated lengths by years of life of 81 fish measured and 
"scaled" during the fish census of June 24-28, 1941, table 12, indicate that these fish reached legal length (10 inches) during the second summer of life and continued to grow rapidly throughout their life span. Fig. 2 shows a growth curve of Onized Lake largemouth bass, based on calculated lengths from scale measurements, with a similar growth curve for the bass in Sportsmen's Lake, a small section of the gravel pit lakes near Lincoln, Illinois (Thompson \& Bennett 1939).

At the time of the poison census of Sportsmen's Lake, May 20, 1938, that

Table 11.-Age-length frequencies of the 275 largemouth bass collected from Onized Lake in the census of June 24-28, 1941. The census was made about $11 / 2$ months after the spawning season, and the lengths shown for each age include the growth increment for the early part of the 1941 season.

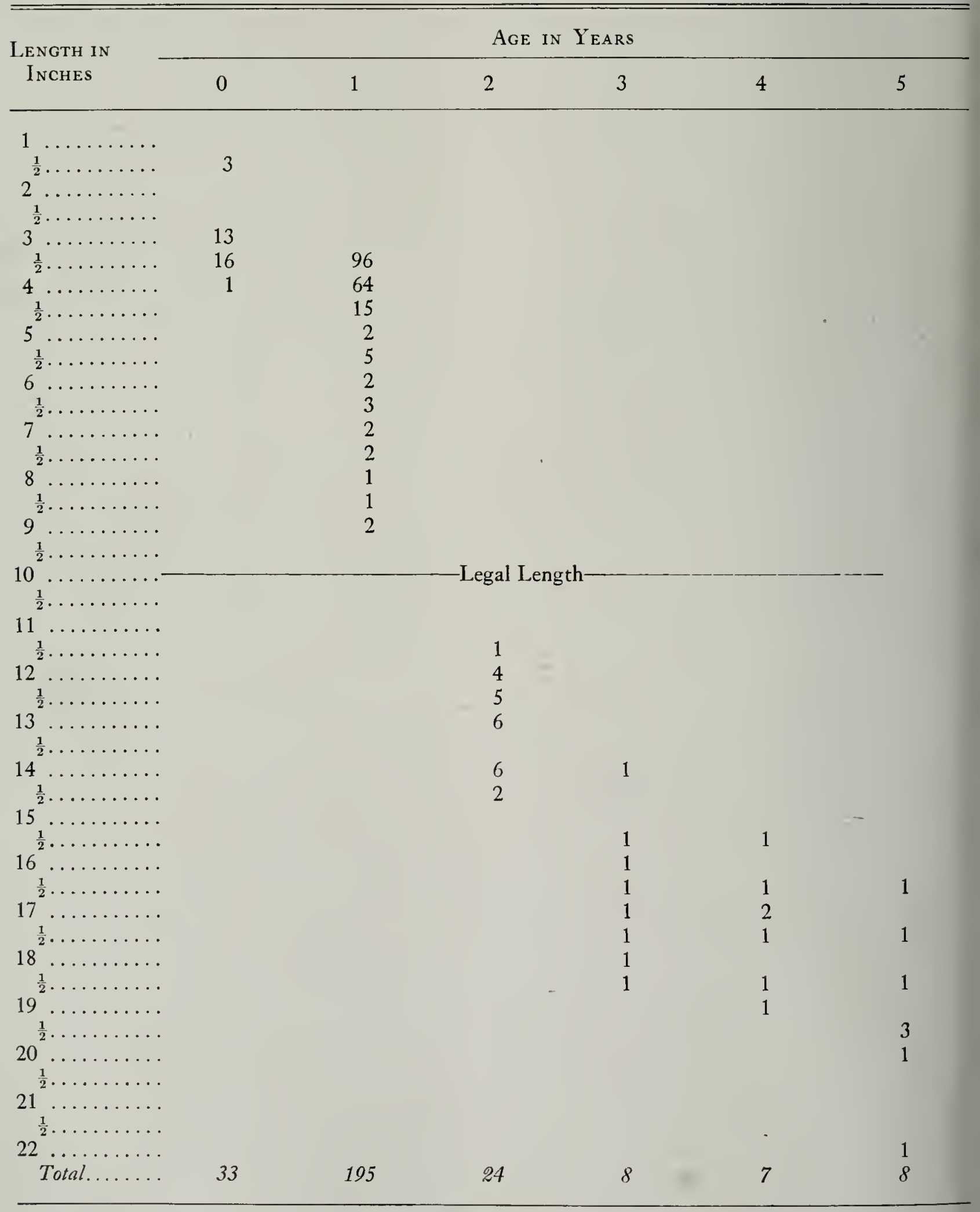


Table 12.-Average calculated total lengths in inches of 81 largemouth bass collected from Onized Lake in the census of June 24-28, 1941.

\begin{tabular}{|c|c|c|c|c|c|c|c|}
\hline \multirow[t]{2}{*}{ BROOD } & \multirow{2}{*}{$\begin{array}{c}\text { Number } \\
\text { OF } \\
\text { Fish }\end{array}$} & \multicolumn{5}{|c|}{$\begin{array}{c}\text { Average Calculated Length by } \\
\text { Years of Life }\end{array}$} & \multirow{2}{*}{$\begin{array}{l}\text { Average Total } \\
\text { Length at Time } \\
\text { of Collection }\end{array}$} \\
\hline & & 1 & 2 & 3 & 4 & 5 & \\
\hline 1936. & 8 & 1.68 & 9.40 & 13.21 & 16.24 & 18.56 & 19.15 \\
\hline 1937. & 7 & 4.81 & 10.32 & 14.04 & 16.75 & & 17.32 \\
\hline 1938. & 7 & 3.93 & 10.83 & 14.90 & & & 16.64 \\
\hline 1939. & 17 & 4.07 & 11.15 & & & & 12.78 \\
\hline 1940. & 42 & 3.07 & & & & & 4.79 \\
\hline Total... & 81 & & & & & & \\
\hline Average. & & 3.37 & 10.58 & 14.01 & 16.48 & 18.56 & \\
\hline
\end{tabular}

body of water contained a bass population that comprised 13.2 per cent of the weight of all fish present.

In comparing the growth curves of largemouth bass in these two lakes, fig. 2, it is of interest to note that bass growth in Onized Lake was relatively poor during the first summer, but rapid in subsequent growing seasons, and that the Onized Lake fish reached legal length when almost a year younger than those of Sportsmen's Lake. Slow first season growth is also indicated for Onized Lake in fig. 3, where the growth curve of bass in this Illinois lake is shown with that of 618 bass from $W$ isconsin and 30 from Louisiana (Bennett 1937). The first sea- son growth of bass in Onized Lake was less than the growth of the Louisiana bass and about equal to that of the Wisconsin bass. The Illinois fish exceeded the $W$ isconsin fish in size after the first year and approached the Louisiana bass in size in the second and third years of life, falling short of the southern fish during the fourth and fifth years. The explanation of poor first year growth seems to relate to severe competition among young fish of all species in Onized Lake. The continually large catch of adult fish reduced predation on the young to the extent that an entire growing season was required to decimate their numbers. Meanwhile, because of food competition among these young fish,

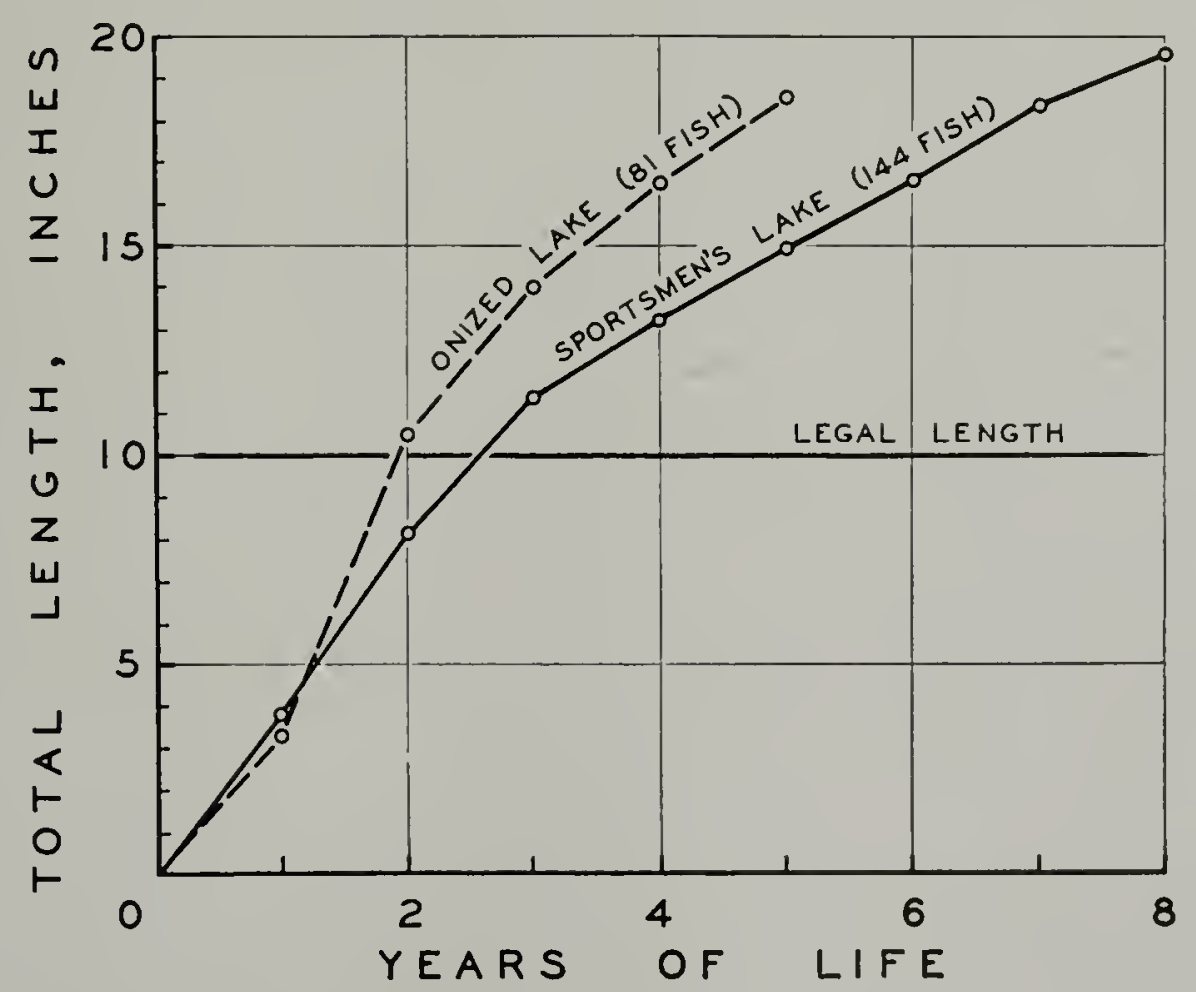

Fig. 2.-Average rate of growth of largemouth bass taken from Onized Lake in the $19+1$ census, and from Sportsmen's Lake (old gravel pit) near Lincoln, Illinois. 


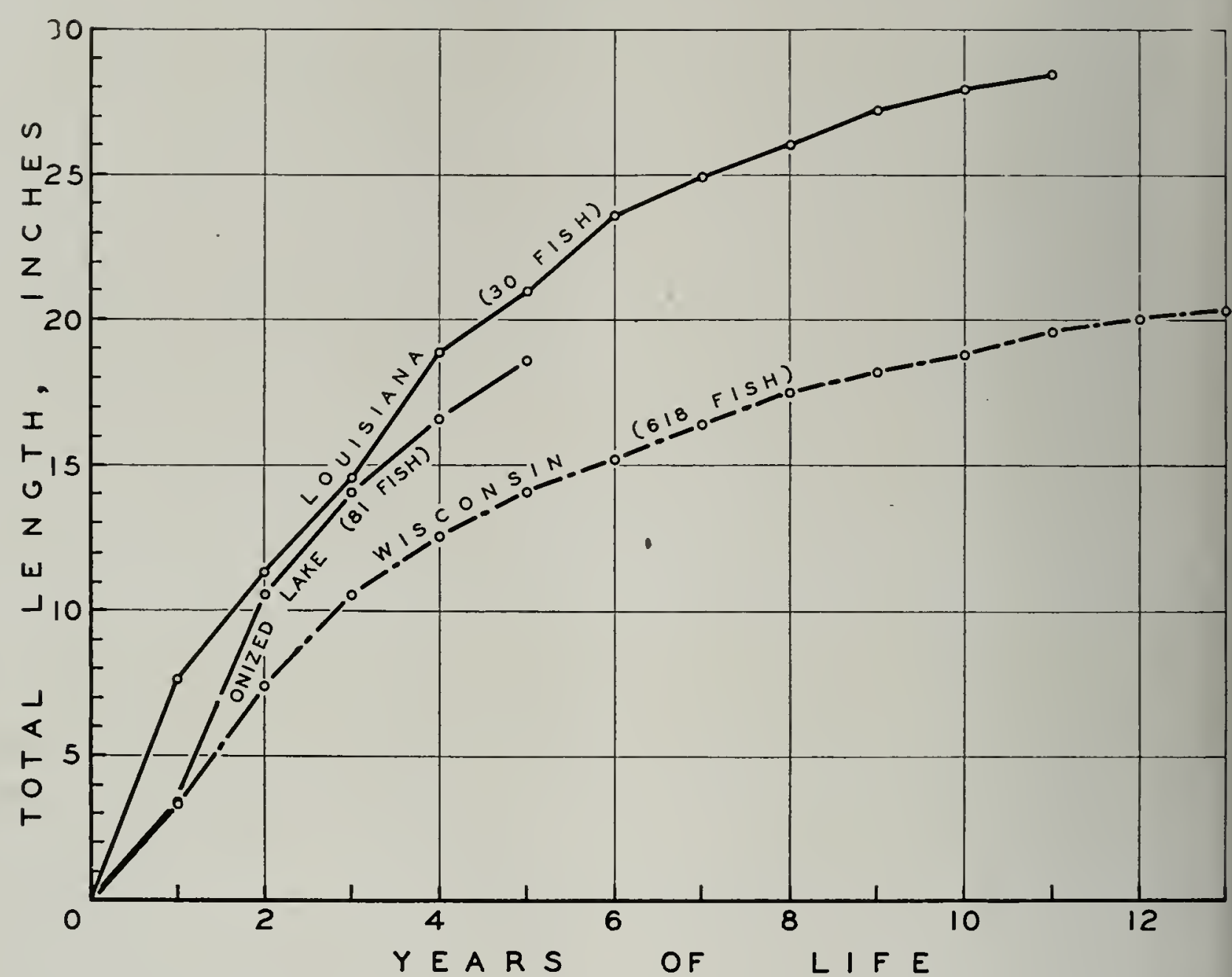

Fig. 3.-Average rate of growth of largemouth bass taken from Onized Lake, from Wisconsin and from Louisiana. The Onized Lake bass averaged about the same size as the Wisconsin bass in the first year and approached the size of the Louisiana bass during the second and third years.

their growth rate was slow. Once the young bass became large enough to prey on other fish, they began to grow rapidly.

\section{Black Crappie}

Pomoxis nigro-maculatus (Le Sueur)

The black crappie population at the time of the $19+1$ census had become reduced to 22 fish. Information gathered from net fishing in 1938 and 1940, and from the catch of black crappies made by fishermen in 1939, 1940 and 1941, indicates that the lake contained a large crappie population at the beginning of the 1939 fishing season and a somewhat larger population in $19+0$ than was taken in the 1941 census.

The lengths of the 22 crappies taken in the 1941 census are recorded in table 13 . Only seven were large enough to interest fishermen; the others were second summer fish of small size. Although a few small fish undoubtedly belonging to the 0 group (spawned in 1941) were seen when the poison was applied, none were collected, and it is probable that they were eaten by fish, turtles and crayfish, or were lost among the mats of vegetation.

It is impossible to say whether the crappies could have returned to their former population level in Onized Lake in competition with the other species of fish present. Certainly the number taken in the final census was sufficient to replenish this population with a single successful spawn, if the young were able to survive predation from a strong bass population.

Studies of crappies in other lake census work in Illinois (Bennett 1943) indicate that the black crappie is rarely as numerous as the white crappie, Pomoxis annularis Rafinesque, in small artificial lakes. Not only were there more stunted populations of white crappies than black in the lakes censused, but in 14 lakes where both species were present the white crappies were more abundant in all but 2 . 


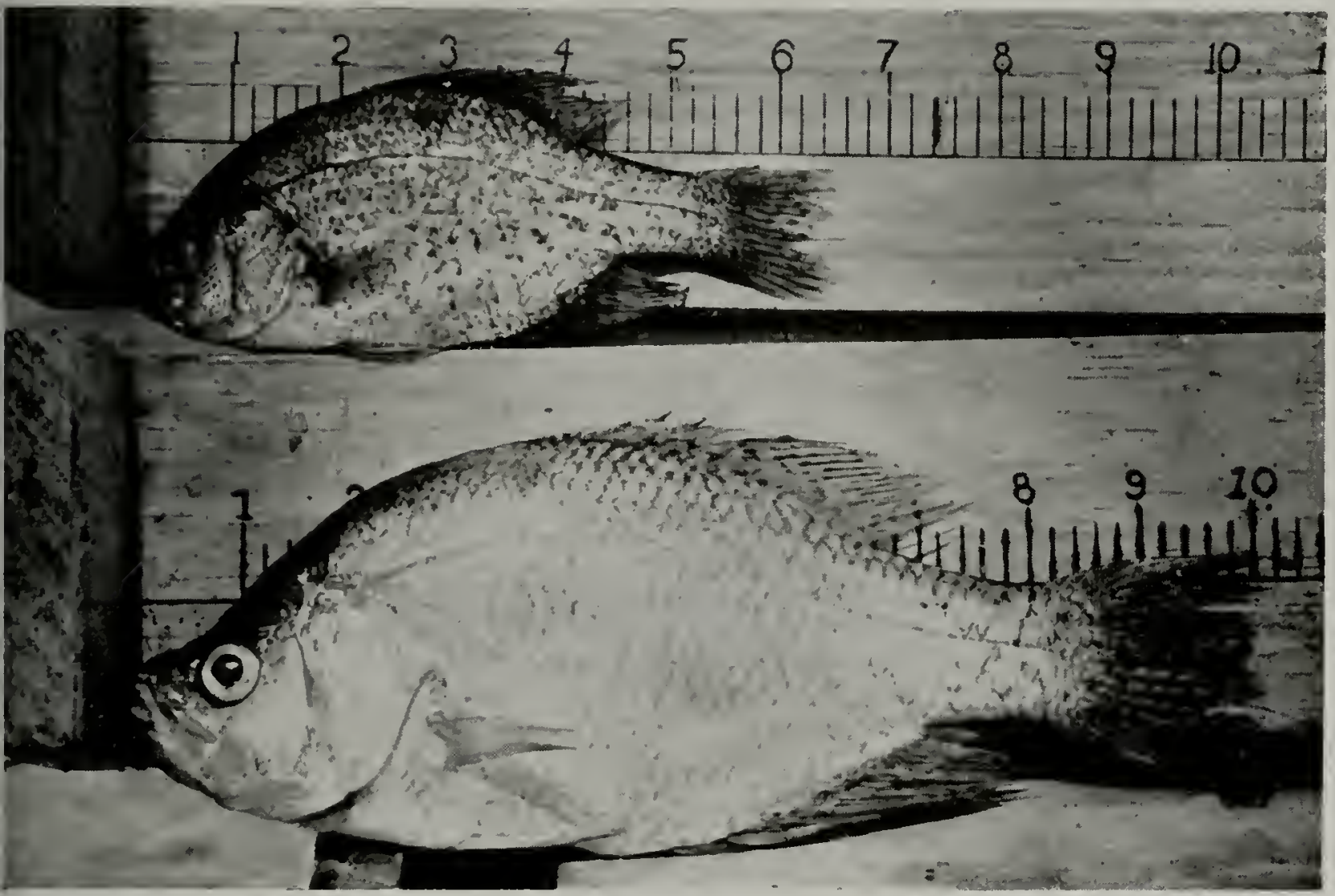

Black crappies taken in hoopnets from Onized Lake in 1940. These crappies were 1 1 and $2: 2$ years old.

Scales and total length measurements from crappies taken from hoopnet collections in 1938 and 1940, and from 21 of the 22 fish taken in the final census, were used in calculating the lengths shown in tables 14,15 and 16 .

The lengths of black crappies collected from Onized Lake are plotted in fig. 4. No crappies older than four summers are known to have been taken from the lake during this study. Calculated lengths of the 1938 and $19+1$ crappie collections showed relatively slow growth rates for the first vear, and a marked increase during the second growing season. 'The 1940 collection included 226 crappies in their second summer of life (1939 brood) that averaged +.02 inches for calculated first year growth, or about a half more than the first year lengths for the other collections. Most of the fish of the 1940 collection were spawned in the year of the greatest hook-and-line yield, and their rapid growth may have been related to an abundant food supply resulting from the removal of many fish. Growth stimulation caused by an increased amount of available food brought about by one of several possible situations has been observed in
Table 13.-Age-length frequencies of the 22 black crappies collected from Onized Lake in the census of June 24-28, 1941. The census was made about $1 \frac{1}{2}$ months after the spawning season, and the lengths shown for each age include the growth increment for the early part of the 1941 season.

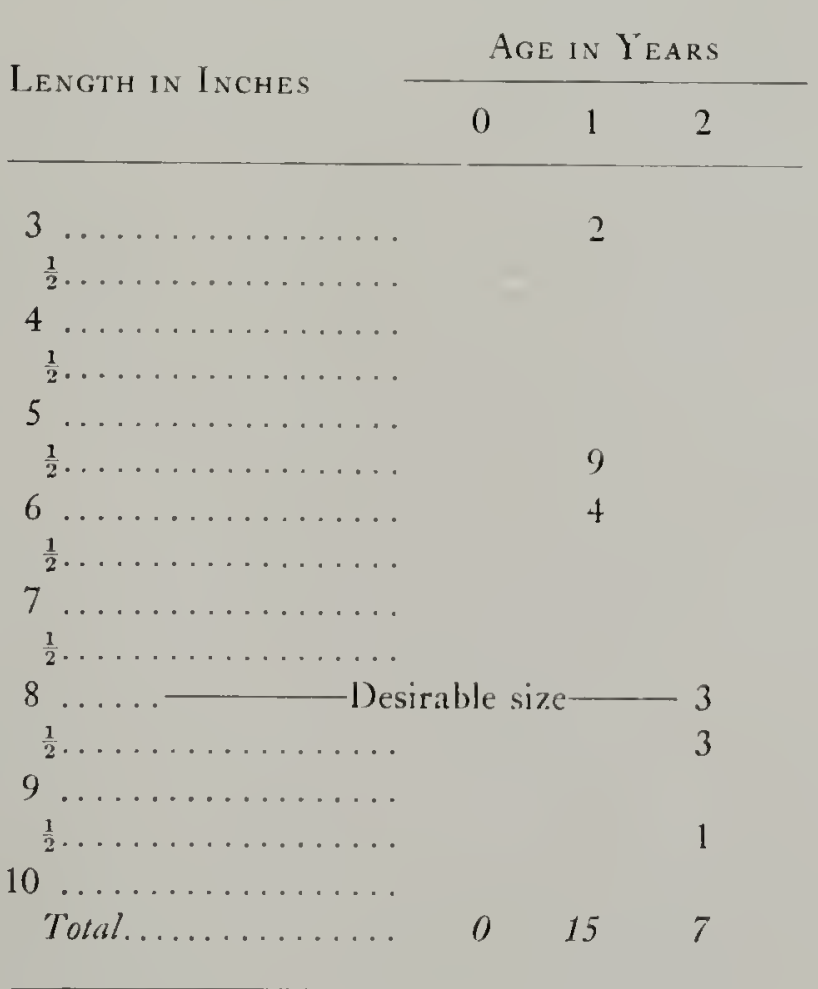


Table 14.-Average calculated total lengths in inches of 98 black crappies collected with hoopnets from Onized Lake, August 29-31, 1938.

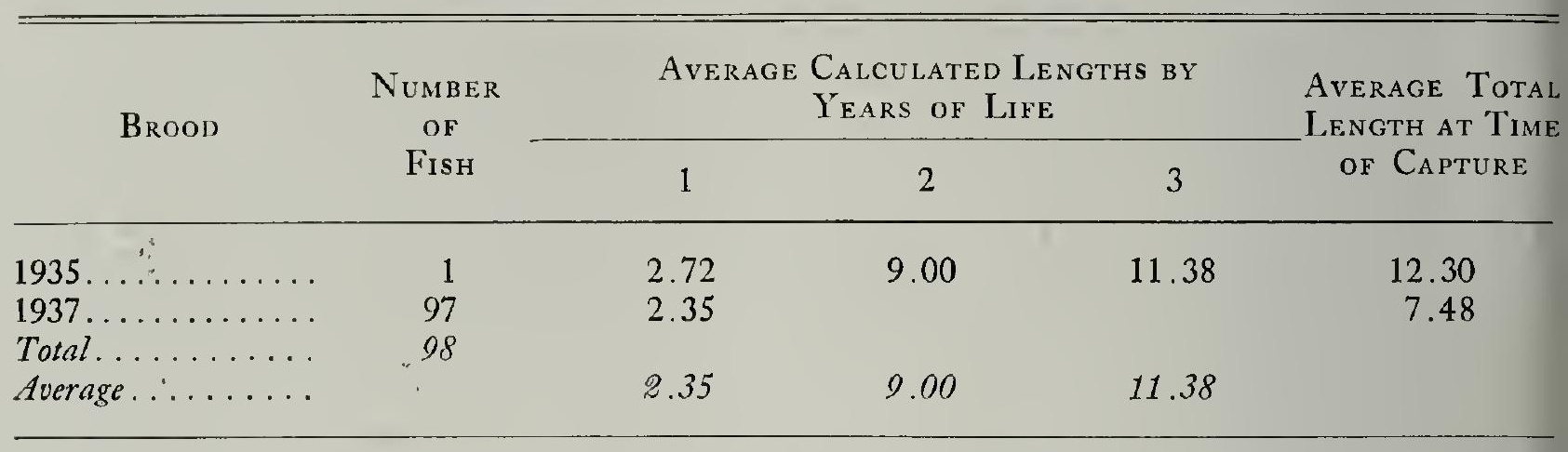

fish many times (Beckman 1941; Bennett, Thompson \& Parr 1940; and others). It lasts until natural reproduction supplies a sufficient number of individuals to cause severe competition for food. In the case of Onized Lake, in which the increased growth rate observed in the 1940 collections did not persist, it must be assumed that, as the population of crappies was not being replaced adequately by natural reproduction, some other species (possibly young bluegills or warmouth bass) offered sufficient competition to the young crappies to reduce their first year growth rate to about that of the 1937 brood.
A few growth studies made on the black crappie supply some information on the yearly length increment of this fish in waters of other states. Eschmeyer \& Jones (1941) include the black crappie in their study of the growth of game fish in Norris Reservoir, and Schoffman (1940) gives data on black crappie growth in Reelfoot Lake. Material from these sources, along with calculated lengths of black crappies from Onized Lake, 1940 collection, has been used in the drafting of fig. 5. The growth curve for Norris Reservoir is based on age group III of the 1940 collection, which, with the exception

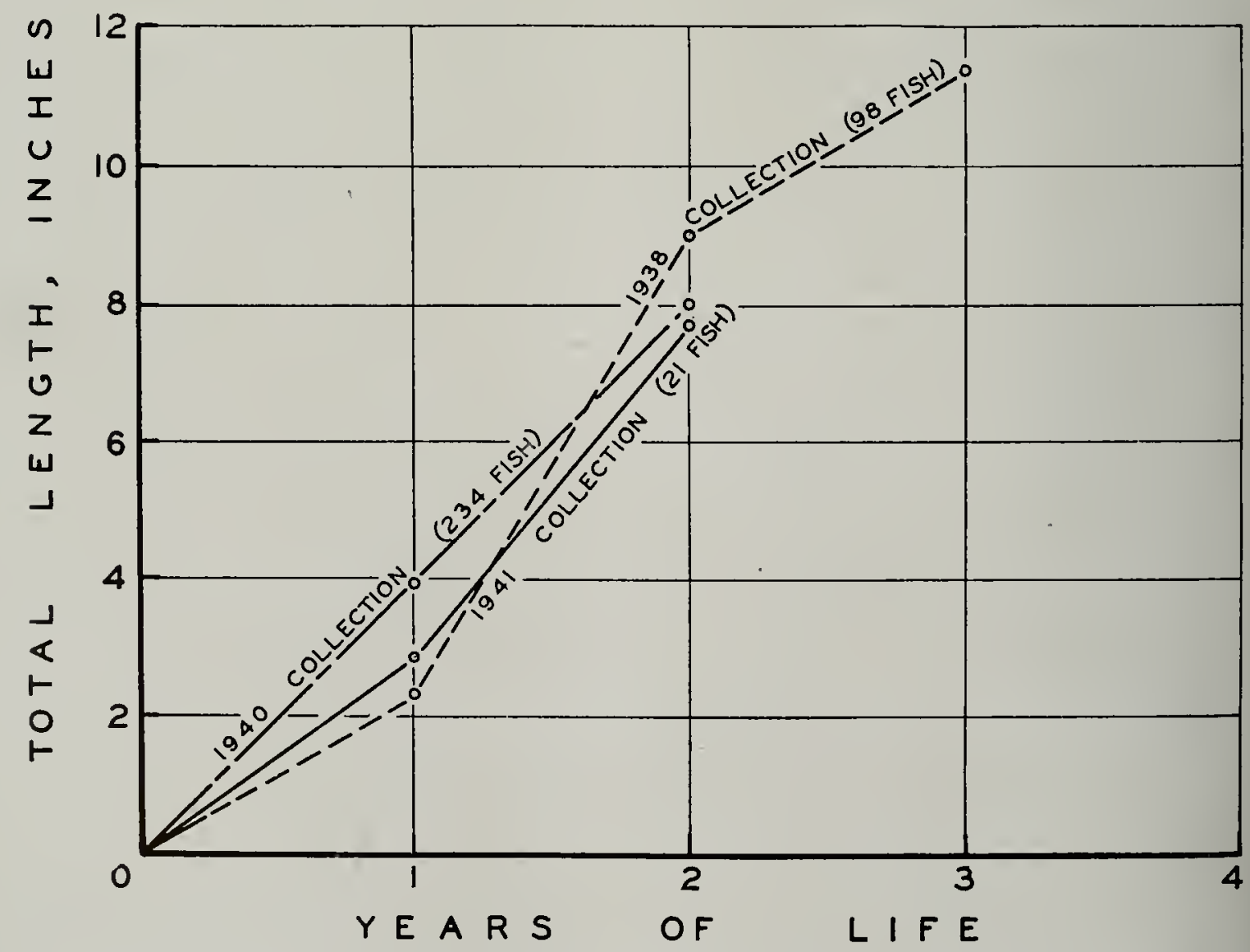

Fig. 4.-Average rate of growth of black crappies taken from Onized Lake as shown by 1938, 1940 and 1941 collections. Crappies spawned in 1939 (1940 collection) showed unusually rapid first year growth. 
Table 15.-Average calculated total lengths in inches of 234 black crappies collected with hoopnets from Onized Lake, July, 1940.

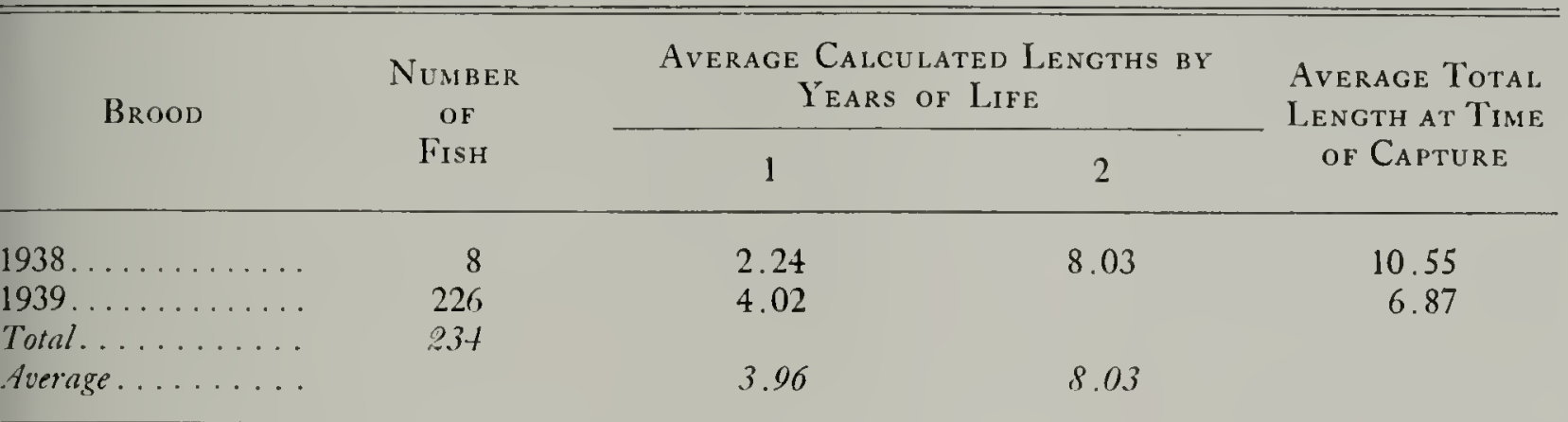

Table 16.-Average calculated total lengths in inches of 21 black crappies collected from Onized Lake in the census of June 24-28, 1941.

\begin{tabular}{ccccc}
\hline \hline \multirow{2}{*}{ Brood } & $\begin{array}{c}\text { Number } \\
\text { of } \\
\text { Fish }\end{array}$ & \multicolumn{2}{c}{$\begin{array}{c}\text { Average Calculated Lengths bi } \\
\text { Years of Life }\end{array}$} & $\begin{array}{c}\text { Average Total } \\
\text { Length at Time } \\
\text { of Collection }\end{array}$ \\
\cline { 3 - 5 } & & 1 & 2 & 8.62 \\
$1939 \ldots \ldots \ldots \ldots \ldots$ & 6 & 3.48 & 7.82 & 5.29 \\
Total $\ldots \ldots \ldots \ldots \ldots$ & 21 & 2.66 & & \\
Average $\ldots \ldots \ldots \ldots$ & & 2.89 & 7.82 & \\
\hline
\end{tabular}

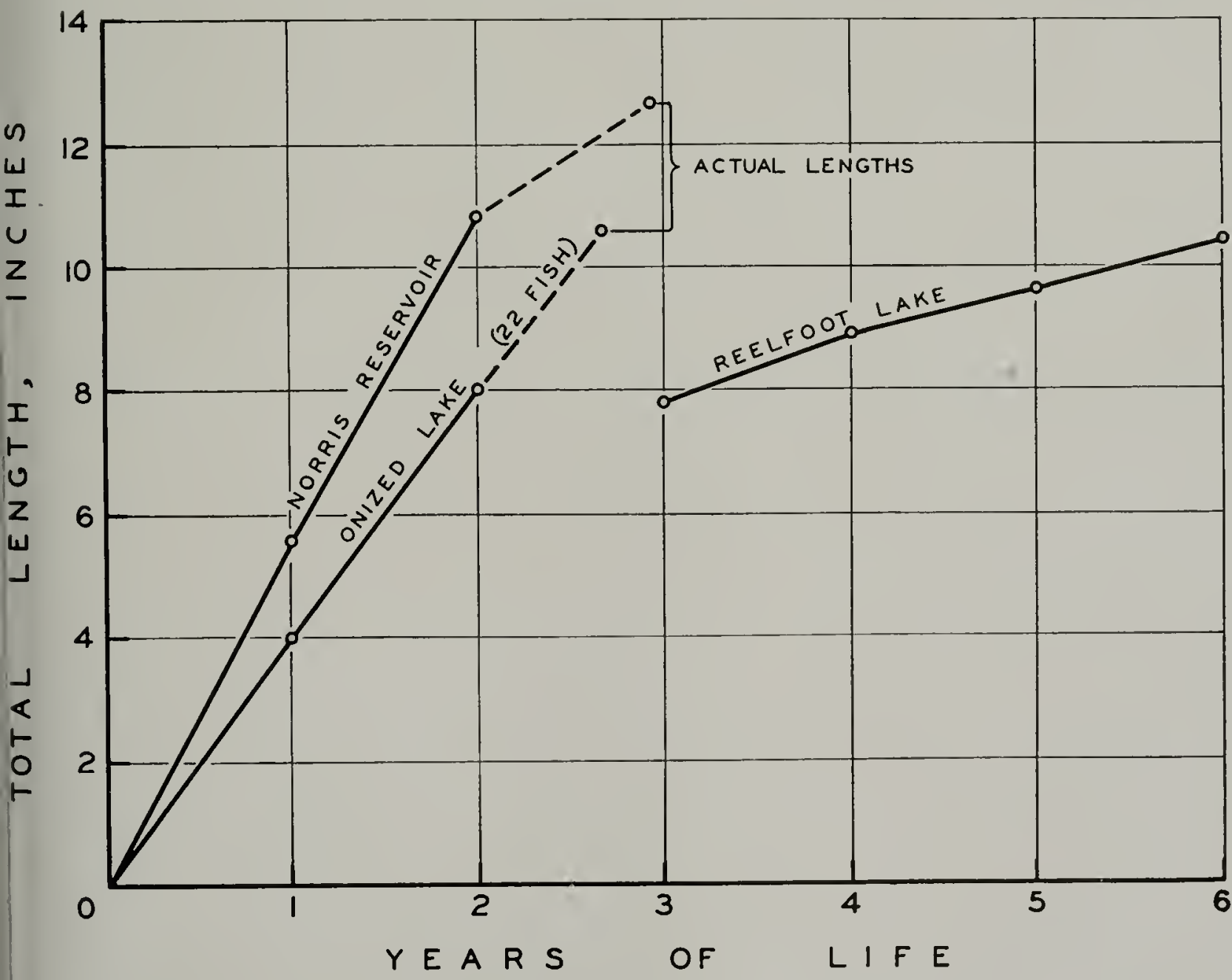

Fig. 5.-Average rate of growth of black crappies in Onized Lake as shown by $19+0$ collection, in Norris Reservoir and in Reelfoot Lake. 
of age group II of the 1939 collection, shows the largest first-year growth. Schoffman's data are based on the average actual lengths of fish on which ages were determined. Points at the extremities of the Norris Reservoir and the Onized Lake curves represent average actual lengths of fish at the time of capture. As shown in fig. 5, the growth curve of the black crappies from Onized Lake lies between the other two, indicating that the Onized Lake fish grew faster than those of Reelfoot, but less rapidly than those of Norris Reservoir.

The excessive cropping of Onized Lake resulted in an unusually rapid rate of growth of black crappies. Schoffman (1940) in his study of Reelfoot Lake black crappies suggests that the minimum legal length of crappies in Tennessee be increased from 8 to 9 inches, in order to give them grcater protection and "since the greatest weight per length is reached in the 8th summer." An assumption of this kind is not valid, because fish growth, within limits, is a reflection of food abundance.

\section{Bluegill \\ Lepomis macroclirus Rafinesque}

Bluegills apparently thrive under conditions of intensive fishing. Not only did this species make up 60.9 per cent of the number and 48.1 per cent of the weight of all fish taken by fishermen from Onized Lake, 1938-1941, table 5, but, in the final fish census, bluegills represented 71.4 per cent of all fish present, and their weight was 52.7 per cent of the weight of all fish. As recorded in the creel census, the average weight of 2,433 bluegills caught wals 0.23 pound, table 5 ; a fish of this weight has a length of slightly more than 6 inches. The largest bluegill recorded by the custodian weighed approximately 1 pound. Bluegills caught and recorded in the creel census of 1939 averaged larger, weighing 0.25 pound each, than in succeeding years; in $19+0$, the average weight was 0.21 pound and, in $1941,0.18$ pound, table 5 . Table 17 gives the age-length frequencies of the bluegills taken in the $19+1$ census. As many of these fish were not accurately aged or measured, but sorted into age groups on the basis of their size range, this table is an estimate of the actual agelength distribution of the population. No fish in the collections were much more than 3 years (in fourth summer) of age.

As in similar tables for other species, the number recorded for 1941 brood bluegills does not represent the actual number in the lake at the time of poisoning. The $19+1$ brood probably exceeded the $19+0$ brood in number of individuals. The number of individuals of desirable sizes listed in table 8 represents an accurate

Table 17.-Age-length frequencies of the 6,545 bluegills collected from Onized Lake in the census of June $24-28,1941$. The census was made about $1 \frac{112}{2}$ months after the spawning season, and the lengths shown for each age include the growth increment for the early part of the 1941 season.

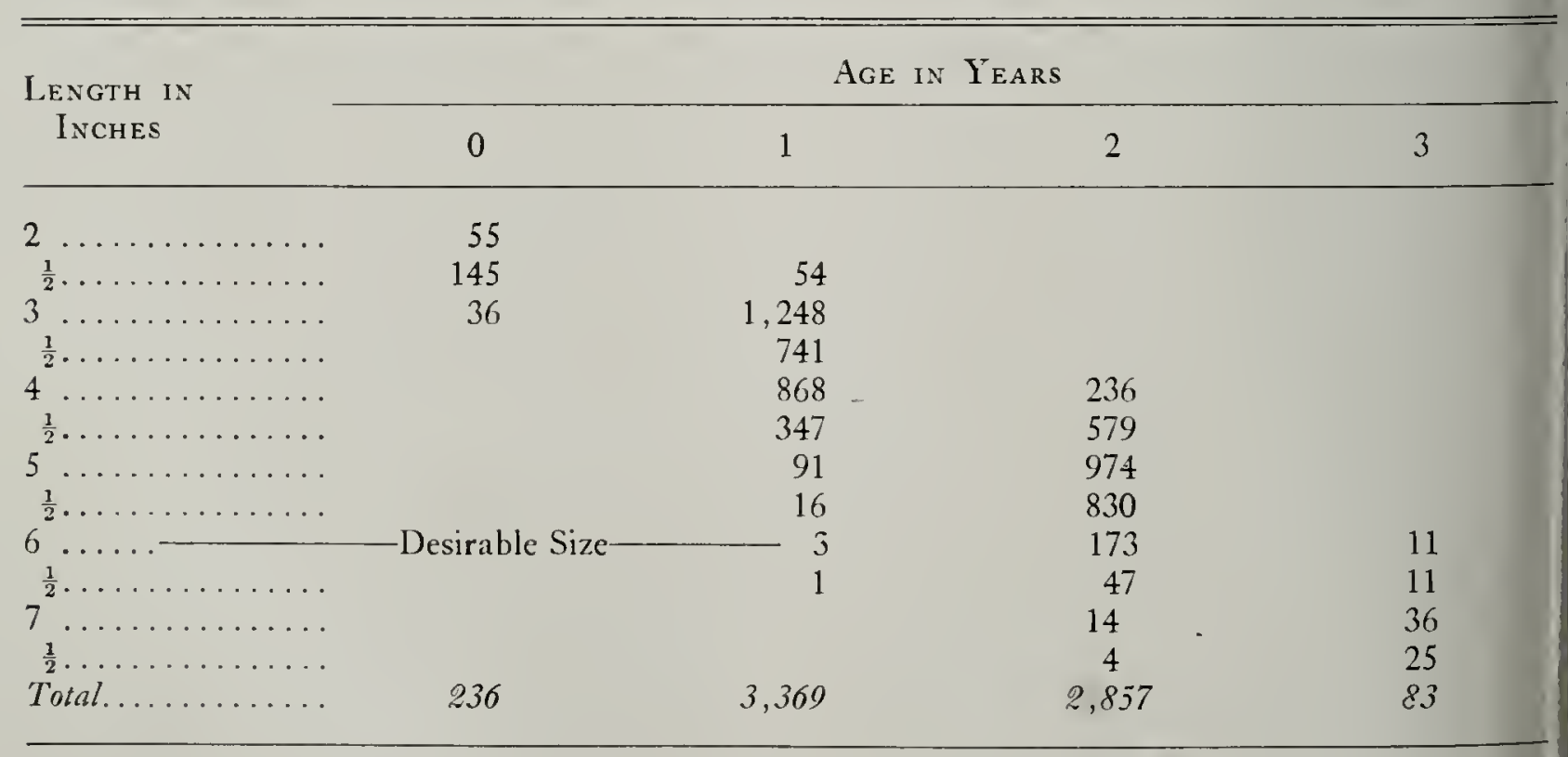


count; great care was taken in sorting out individuals of 6 or more inches in length. The ratio of bluegills of desirable sizes to those smaller was $1: 19$; that is, the number of bluegills of desirable sizes represented about 5 per cent of the total number of bluegills. Because an accurate count of the $19+1$ brood could not be made, the calculated percentage of large fish was much larger than the actual percentage.

Tables 18, 19 and 20 show calculated lengths of bluegills taken in the hoopnet collections of 1938 and 1940, and in the census of 1941. Growth curves based on these lengths, fig. 6 , show some variation in growth rates of bluegills represented by each of these three collections. Unlike the black crappies, bluegills spawned in 1939 apparently made no abnormal growth increment during that year. Abnormal growth in bluegills spawned early might be obscured by the growth figures of those spawned in July and August; it also seems that the growth of bluegills was less stimulated by the results of heavy fishing than was that of most other species.

Other sources of information relative to bluegill growth in Illinois are available.

Table 18.-Average calculated total lengths in inches of 53 bluegills collected with hoopnets from Onized Lake, August 29-31, 1938.

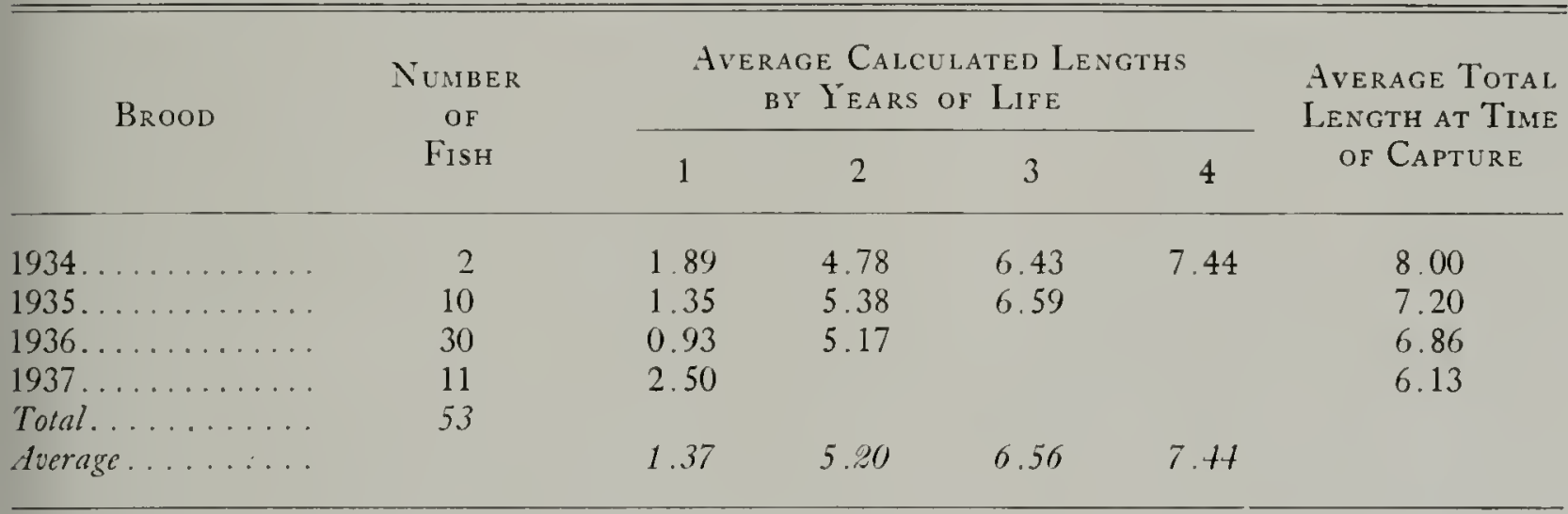

Table 19.-Average calculated total lengths in inches of 99 bluegills collected with hoopnets from Onized Lake, July 9-15, 1940.

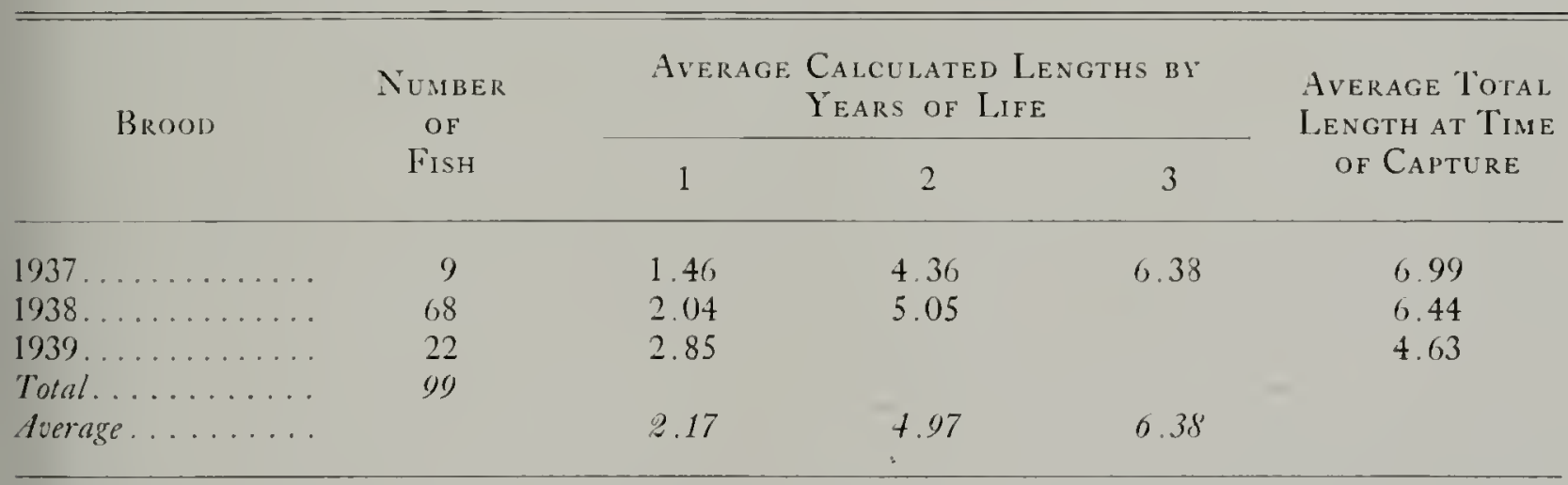

Table 20.-Average calculated total lengths in inches of 177 bluegills collected from Onized Lake in the census of June 24-28, 1941.

\begin{tabular}{|c|c|c|c|c|c|}
\hline \multirow{2}{*}{ BROOD } & \multirow{2}{*}{$\begin{array}{l}\text { Number } \\
\text { of } \\
\text { Vish }\end{array}$} & \multicolumn{3}{|c|}{$\begin{array}{c}\text { Average Calculated Lengths by } \\
\text { Years of Life }\end{array}$} & \multirow{2}{*}{$\begin{array}{l}\text { Average Total } \\
\text { I.engih at Time } \\
\text { of Capture }\end{array}$} \\
\hline & & 1 & 2 & 3 & \\
\hline$\ldots \ldots \ldots$ & 19 & 1.65 & 4.85 & 6.55 & 7.06 \\
\hline$\ldots \ldots \ldots$ & 143 & 1.78 & 4.28 & & 5.22 \\
\hline $1940 \ldots \ldots \ldots \ldots$ & 15 & 2.55 & & & 4.25 \\
\hline 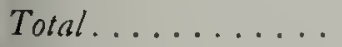 & 177 & & & & \\
\hline Average.......... & & 1.83 & 4.35 & 6.55 & \\
\hline
\end{tabular}


Measurements of 1938 brood bluegills taken from Fork Lake during 1939 (Bennett, Thompson \& Parr 1940) indicate that under uncrowded conditions this species may grow rapidly to useful sizes. Table 21 gives the numbers and average

Table 21.-Numbers and average total lengths in inches of 1938 brood bluegills collected, March through November, 1939, from Fork Lake near Mount Zion, Illinois.

\begin{tabular}{|c|c|c|}
\hline Month & Number & $\begin{array}{l}\text { Average Total } \\
\text { Length, Inches }\end{array}$ \\
\hline$\ldots \ldots \ldots$ & 33 & 3.61 \\
\hline April...... & 37 & 4.32 \\
\hline May............. & 24 & 4.96 \\
\hline June............ & 174 & 5.24 \\
\hline July.... & 116 & 5.41 \\
\hline August...... & 77 & 5.81 \\
\hline September........ & 197 & 5.99 \\
\hline October.......... & 87 & 6.30 \\
\hline November........ & 28 & 6.30 \\
\hline Total..... & 773 & \\
\hline
\end{tabular}

total lengths of 1938 brood bluegills collected from Fork Lake throughout the 1939 growing season.

Schloemer (1939) included in his study of bluegill growth the uncorrected calculated lengths of bluegills taken in hoopnet collections from five Illinois lakes. Most of these collections were furnished, 19301938 , by Dr. Donald F. Hansen of the Natural History Survey. The collections were from Grass and Pistakee lakes (glacial), in northern Illinois, Senachwine and Chautauqua lakes (bottomland lakes adjacent to the Illinois River) in the central part of the state, and Horse Shoe Lake (old Mississippi River oxbow) in the extreme southern end. The calculated lengths of bluegills from each of these lakes were averaged to give the growth rate shown in table 22 .

The average growth of bluegills in Onized Lake (1941 census) and in Fork Lake is compared in fig. 7 with the average growth in the five Illinois lakes studied by

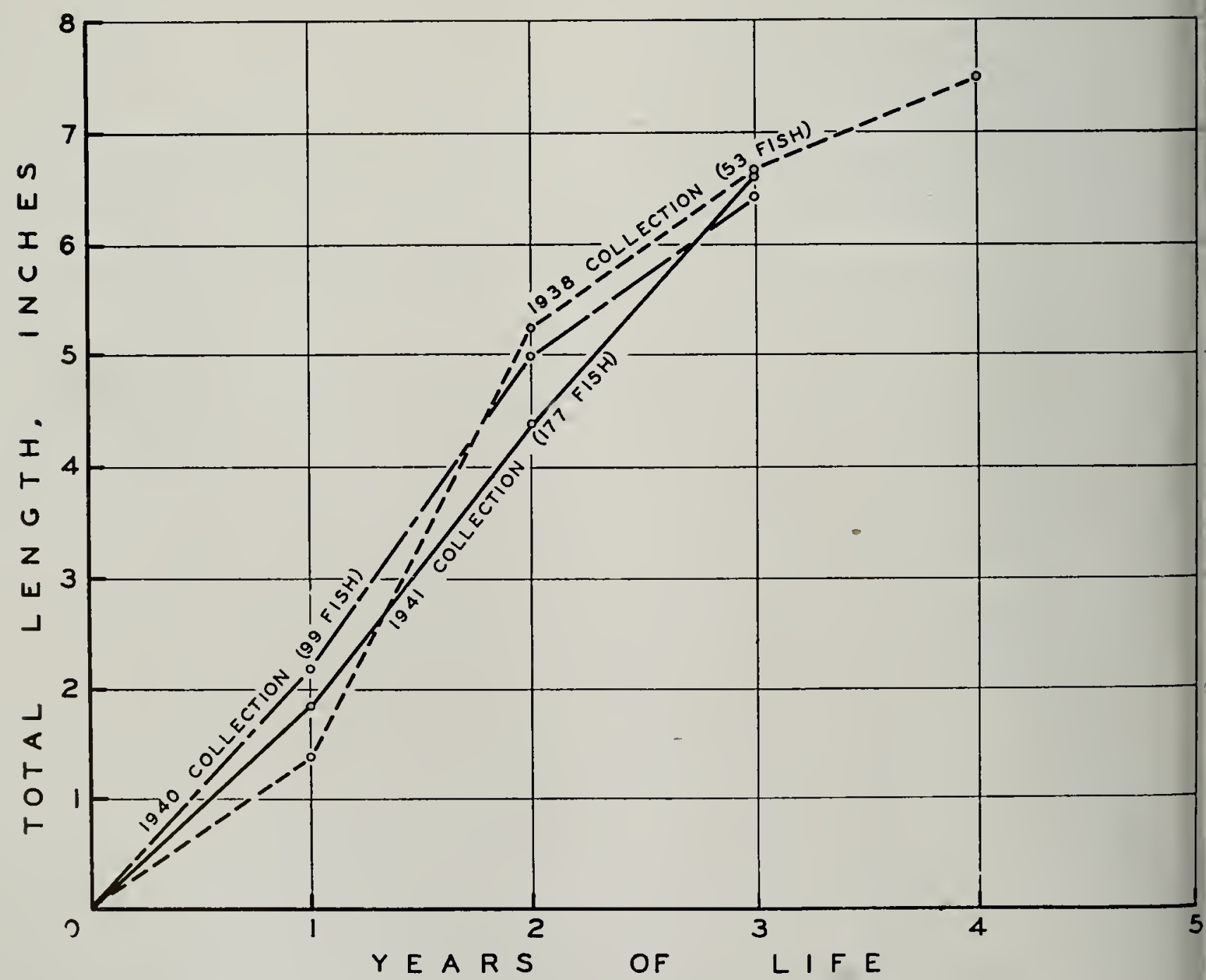

Fig. 6-Average growth rate of bluegills in Onized Lake collections, 1938, 1940 and 1941. 
Table 22.-Average growth of bluegills in Illinois, based on growth in five large bodies of water representing northern, central and southern locations, and three types of lakes.

Average Total Length in lnches at End of Growing Season

\begin{tabular}{cccccccc}
\hline First & Second & Third & Fourth & Fifth & Sixth & Seventh & Eighth \\
1.3 & 3.5 & 4.9 & 6.0 & 6.8 & 8.0 & 8.2 & 8.0 \\
\hline
\end{tabular}

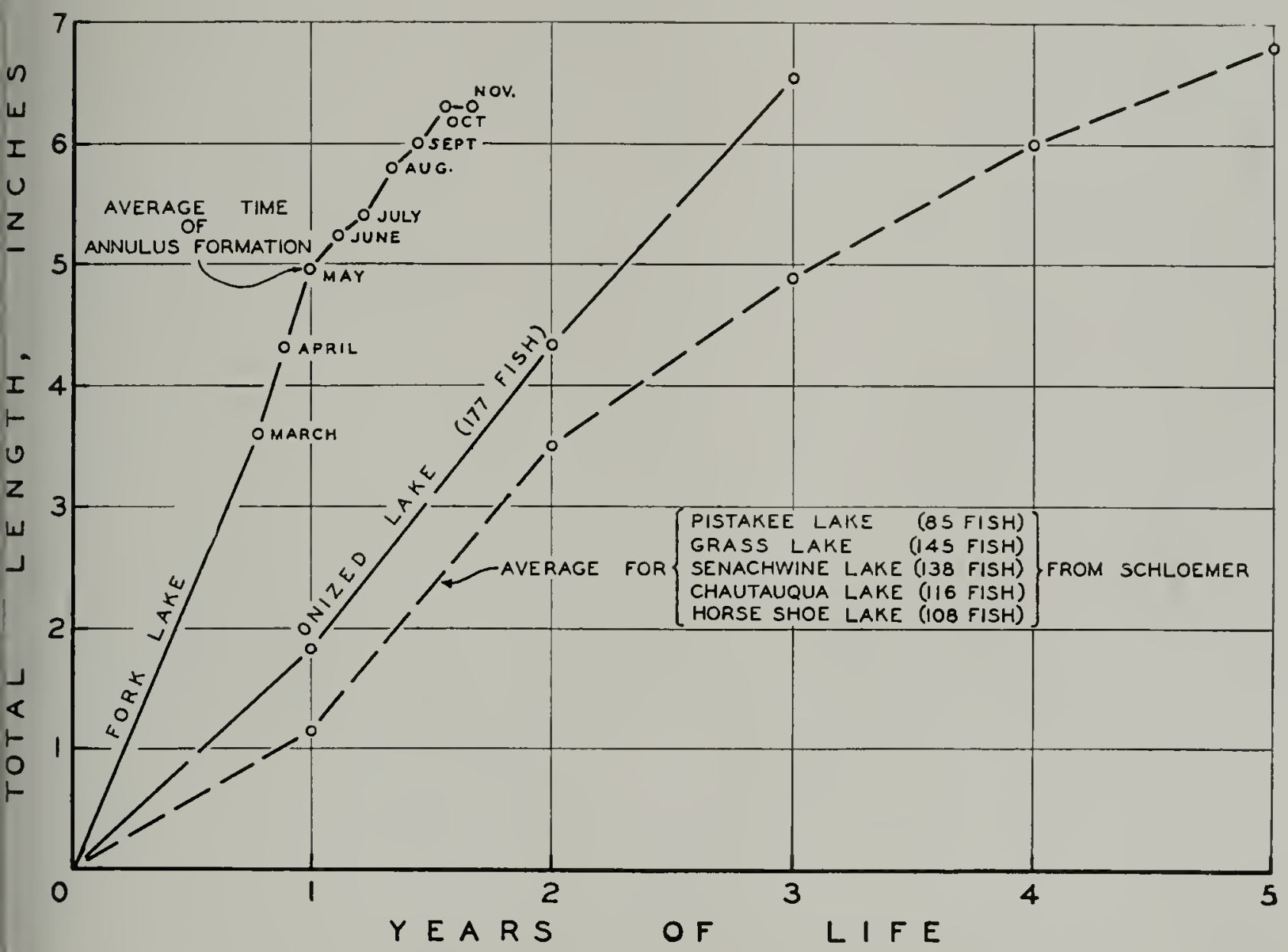

Fig. 7.-Average rate of growth of bluegills in Onized Lake (final $19+1$ collection), in Fork Lake (1938 brood) and in five large natural lakes in Illinois (1930-1938).

Schloemer. Bluegill growth in Onized Lake was considerably faster than that in the five lakes, but much slower than the growth in Fork Lake, where the population was not crowded because the lake had been newly stocked the preceding year and there was little competition for food.

\section{Warmouth Bass}

\section{Chaenobryttus gulosus (Cuvier)}

Warmouth bass were of little value to the fishermen of Onized Lake. Although 1,638 of these fish were collected in the final census (1941), their total weight was only 28.6 pounds, and only 13 were large enough to interest fishermen, tables 7 and 8 . In the yield taken by fishermen (1938-
1941), 105 warmouth bass weighing 33.4 pounds were recorded, table 5.

Table 23 gives the length and age distribution of the warmouth bass collected in the $19+1$ final census of Onized Lake. None of the $19+1$ spawn were seen or collected, but it is probable that because of their small size they were not observed when the treatment was first applied.

Calculated lengths based on scale studies were determined for 101 warmouth bass, which included most of the larger individuals, table $2 t$.

In fig. 8 , the growth curve of warmouth bass from Onized Lake is compared with a growth curve constructed from Schoffman's data (1940) on the warmouth bass in Reelfoot Lake. In Onized Lake the 
Table 23.-Age-length frequencies of the 1,638 warmouth bass collected from Onized Lake in the census of June 24-28, 1941. The census was made about $1 \frac{1 / 2}{2}$ months after the spawning season, and the lengths shown for each age include the growth increment for the early part of the 1941 season.

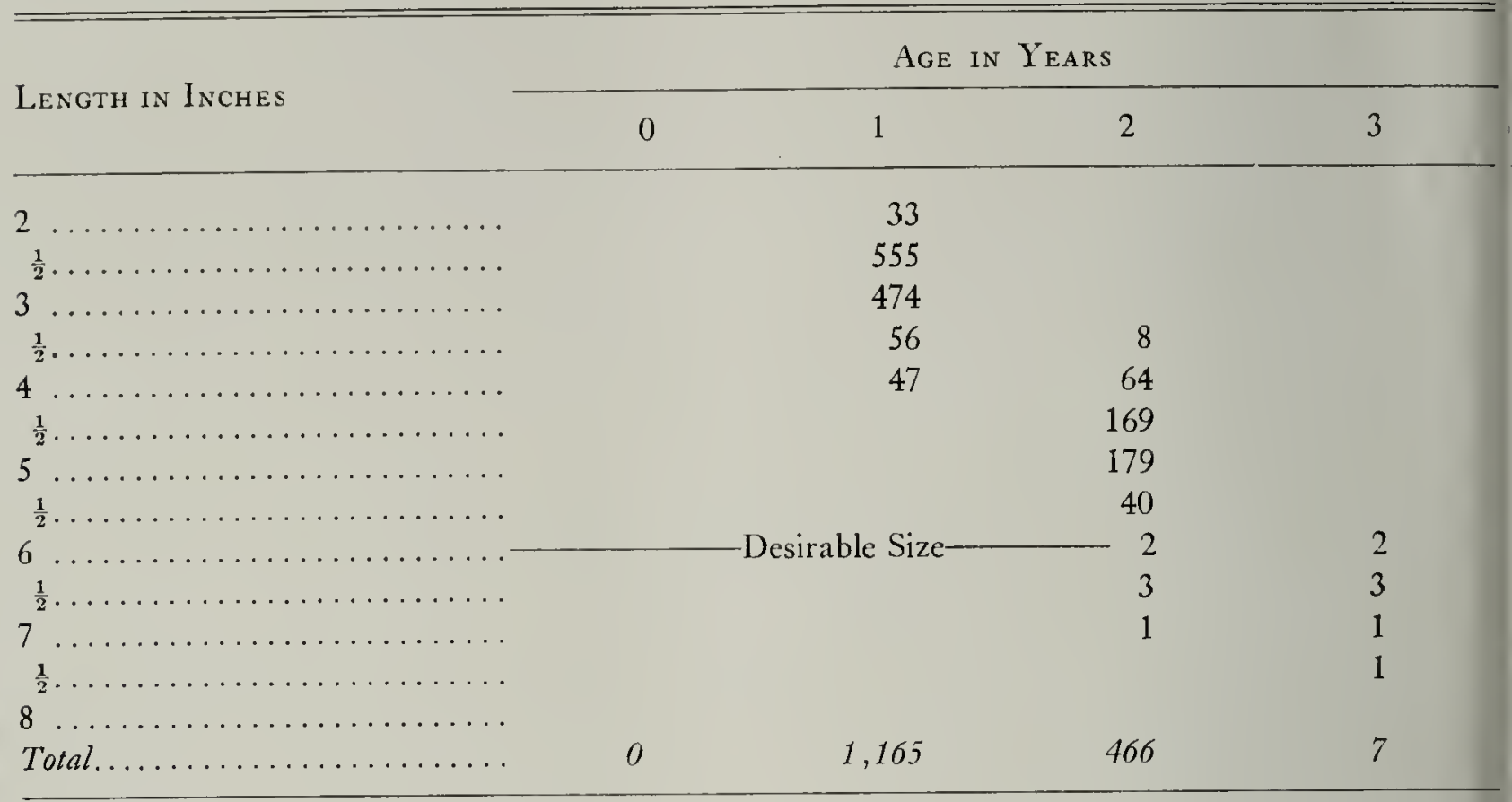

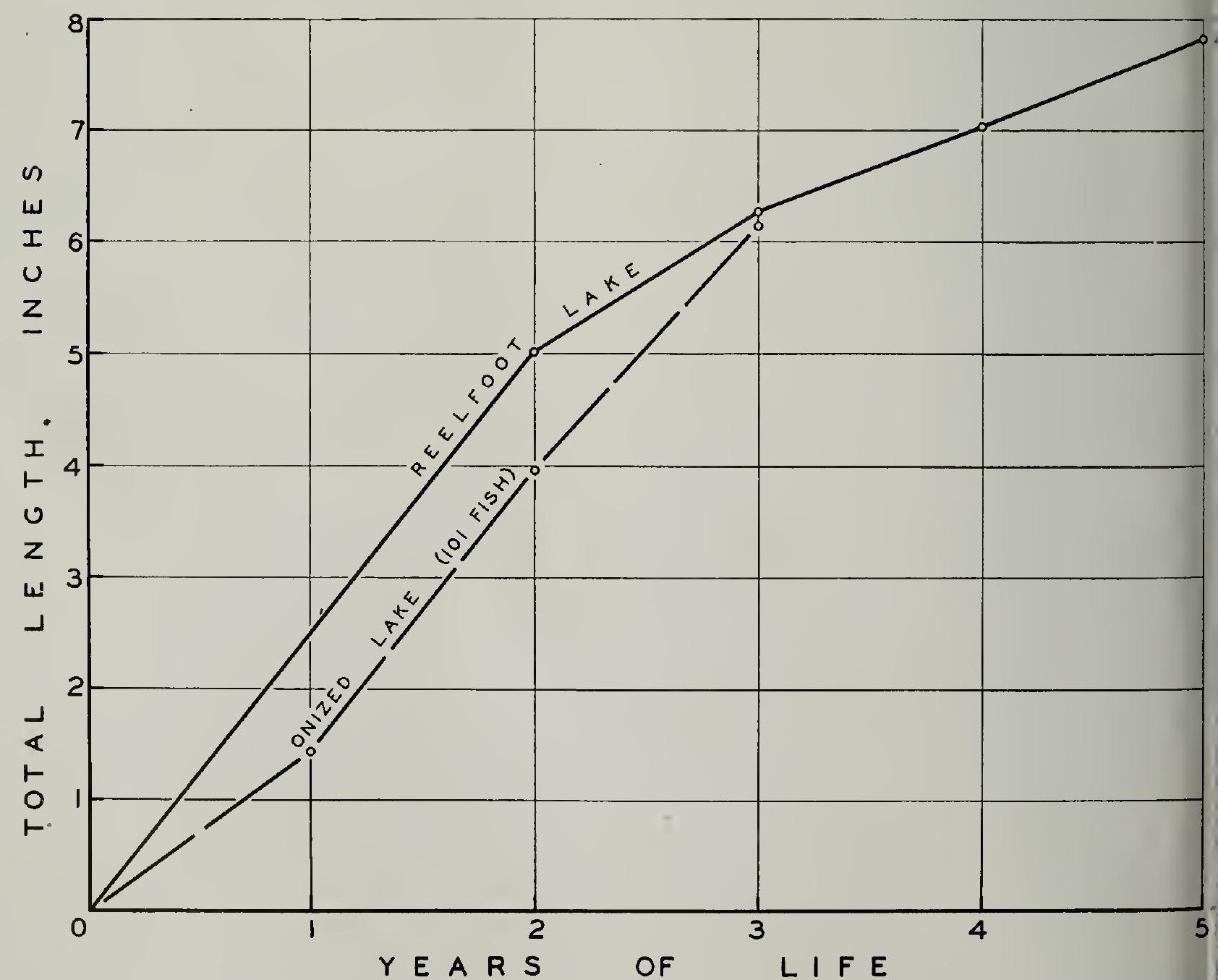

Fig. 8-Average rate of growth of warmouth bass in Onized Lake and in Reelfoot Lake The warmouth bass in Onized Lake grew at approximately the same rate as the green sunfish: íg. 9, and neither of these species was of great importance in the hook-and-line catch. 
Table 24.-Average calculated total lengths in inches of 101 warmouth bass collected from Onized Lake in the census of June 24-28, 1941.

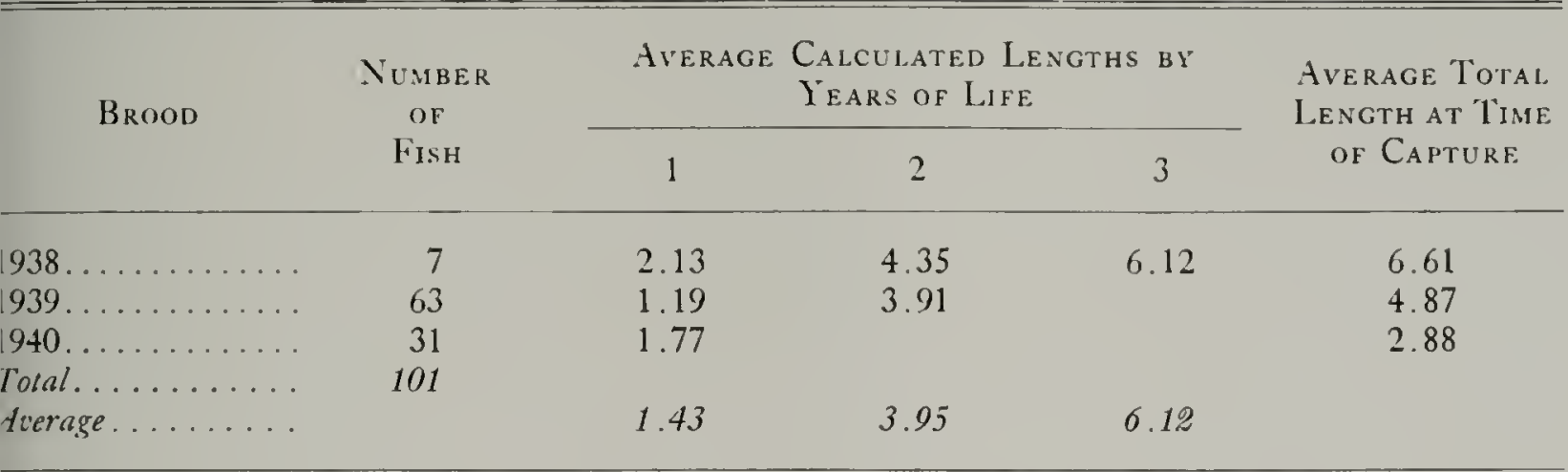

growth rate was slower than that in Reelfoot during the first 3 years of life. Only a few of the warmouth bass in Onized Lake had survived to begin the fourth summer.

The warmouth bass may have some potential value as a fish for managed ponds, but it seems unable to produce usable fish in combination with other species in unmanaged small lakes.

\section{Green Sunfish \\ Lepomis cyanellus Rafinesque}

Green sunfish were more important than warmouth bass in the creel census from Onized Lake, but they failed to make up as much as 10 per cent by weight of the fishermen's catch, 1938-19+1, table 5. In the $19+1$ census, green sunfish were greatly outnumbered by warmouth bass and bluegills, table 7.

Table 25 gives the age-length frequencies of green sunfish. With the exception of one fish of the 1937 brood, the green sunfish collected in the $19+1$ census belonged to the 1938,1939 and $19+0$ broods. The $19+1$ brood was lost in the process of censusing.

The age distribution pattern of green sunfish was nearly identical with that of the warmouth bass, tables 23 and 25 . Only 9 of the 245 green sunfish were 6 inches or more in length. The average weight of this fish in the $19+1$ census was 0.026 pound, while that of the bluegill

Table 25.-Age-length frequencies of the 245 green sunfish collected from Onized Lake in the census of June $24-28,1941$. The census was made about $11 / 2$ months after the spawning season, and the lengths shown for each age include the growth increment for the early part of the 1941 season.

Age in Years

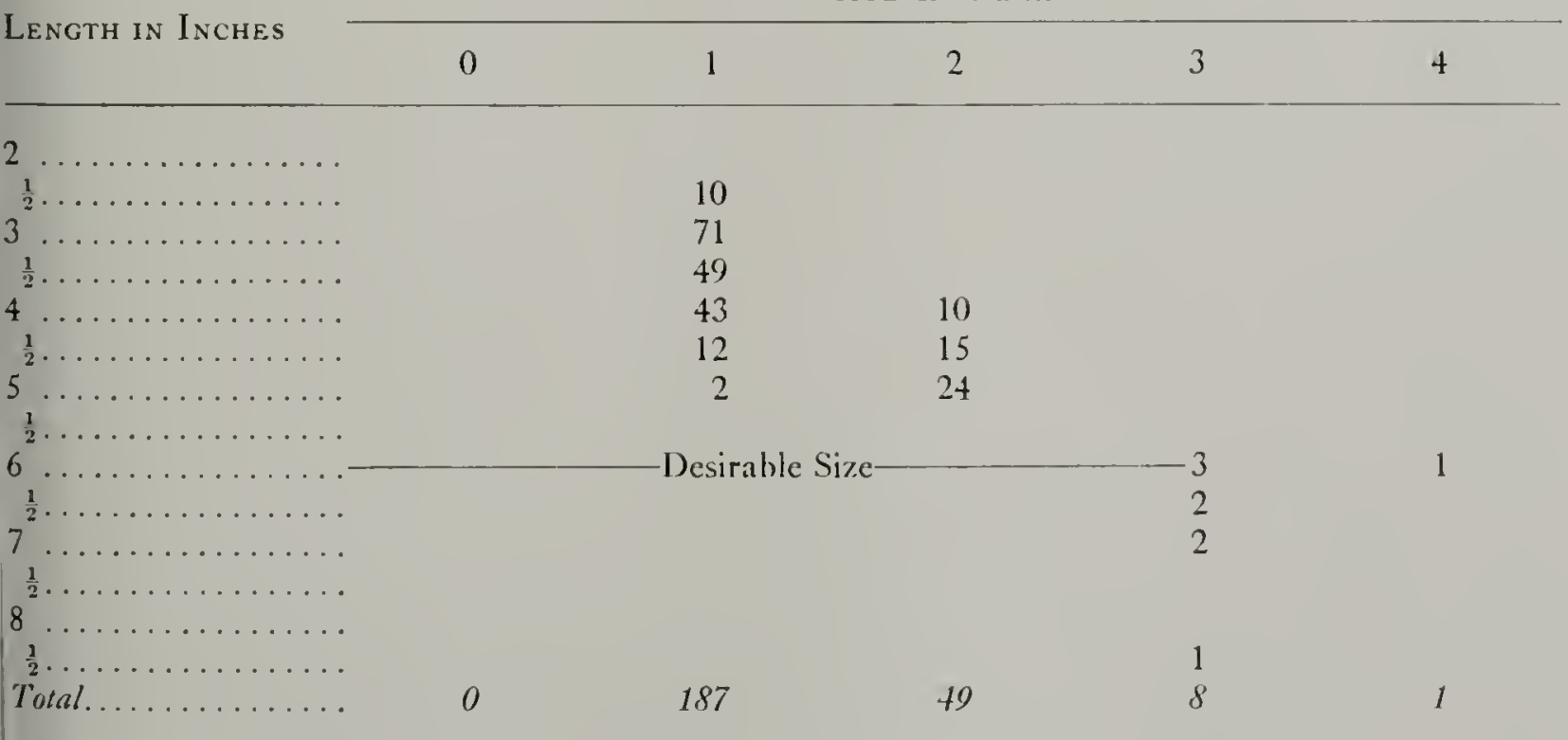


Table 26.-Average calculated total lengths in inches of 95 green sunfish collected from Onized Lake in the census of June 24-28, 1941.

\begin{tabular}{|c|c|c|c|c|c|c|}
\hline \multirow{2}{*}{ BROOD } & \multirow{2}{*}{$\begin{array}{c}\text { Number } \\
\text { of } \\
\text { Fish }\end{array}$} & AvERAGE & \multicolumn{2}{|c|}{$\begin{array}{l}\text { Calculated Lengths } \\
\text { Years of Life }\end{array}$} & BY & \multirow{2}{*}{$\begin{array}{c}\text { Average Total } \\
\text { Length at Time } \\
\text { of Collection }\end{array}$} \\
\hline & & 1 & 2 & 3 & 4 & \\
\hline $1937 \ldots$ & 1 & 0.91 & 4.67 & 5.36 & 5.86 & 6.20 \\
\hline $1938 \ldots \ldots \ldots$ & 6 & 1.95 & 4.42 & 6.16 & & 6.80 \\
\hline $1939 \ldots$ & 21 & 1.61 & 4.12 & & & 4.63 \\
\hline $1940 \ldots \ldots \ldots$ & 67 & 2.16 & & & & \\
\hline Total. & 95 & & & & & \\
\hline Average....... & & 2.01 & 4.20 & 6.05 & 5.86 & \\
\hline
\end{tabular}

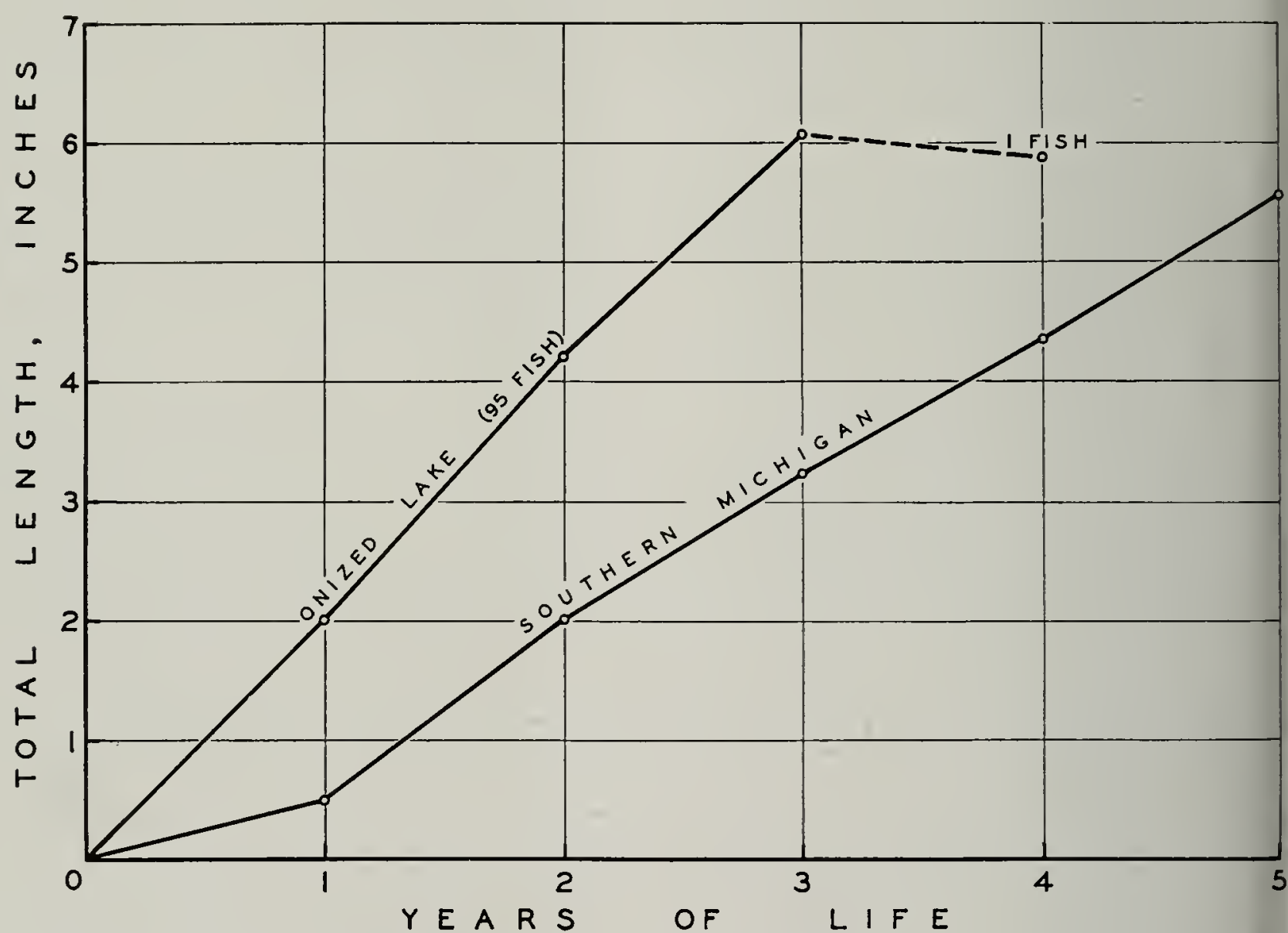

Fig. 9.-Average rate of growth of green sunfish in Onized Lake and in southern Michigan.

was 0.036 pound and of the warmouth bass 0.017 pound, table 7 .

The average calculated total lengths of 95 green sunfish are given in table 26 and a growth curve constructed from these lengths is shown in fig. 9. Also in fig. 9 is shown a growth curve of this species from southern Michigan, based on the data of Hubbs \& Cooper (1935). Apparently in Michigan a combination of stunting and a short growing season limits the number of green sunfish that reach usable size. Hubbs \& Cooper state, "only one fish in thirty-two from the southern zone is of legal size" (6 inches). In Onized Lake, only 1 fish in 27 had reached a length of 6 inches at the time of the 1941 census, tables 7 and 8 .

\section{Yellow Bass \\ Morone interrupta Gill}

Four yellow bass were collected in the final Onized Lake census of 1941, table 7 Their lengths were $11.1,11.4,11.5$ anc 11.5 inches and their weights, $0.50,0.88$ 
Table 27.-Average calculated total lengths in inches of two yellow bass collected from Onized ake in 1938, one in 1940 and three in the final census of June 24-28, 1941.

\begin{tabular}{|c|c|c|c|c|c|c|c|}
\hline \multirow{2}{*}{ BROOD } & \multirow{2}{*}{$\begin{array}{c}\text { Number } \\
\text { of } \\
\text { Fish }\end{array}$} & \multicolumn{5}{|c|}{$\begin{array}{c}\text { Average Calculated Lengths by } \\
\text { Years of Life }\end{array}$} & \multirow{2}{*}{$\begin{array}{l}\text { Average Total } \\
\text { Length at Time } \\
\text { of Collection }\end{array}$} \\
\hline & & 1 & 2 & 3 & 4 & 5 & \\
\hline \multicolumn{8}{|c|}{1938 Collection } \\
\hline 935. & 1 & 1.57 & 7.27 & 9.16 & & & 9.80 \\
\hline 936. & 1 & 2.14 & 8.56 & & & & 10.80 \\
\hline rotal.... & 2 & 1.86 & 7.92 & 9.16 & & & \\
\hline \multicolumn{8}{|c|}{1940 Collection } \\
\hline 936 & 1 & 1.89 & 8.61 & 10.23 & 10.95 & & 11.40 \\
\hline \multicolumn{8}{|c|}{$19+1$ Collection } \\
\hline $936 \ldots$ & 3 & 1.87 & 8.29 & 9.97 & 10.75 & 11.15 & 11.50 \\
\hline
\end{tabular}

0.90 and 0.83 pound, respectively. All the scales collected from the smallest fish were regenerated; ages determined for the ther three fish indicate that they belonged to the 1936 brood, and it is probable that the fourth fish in the collection was of the same age. The total number of yellow bass taken by fishermen in the creel census of 1938-1941 was seven, table 5. Scales from two yellow bass caught in hoopnets in the 1938 fishing period and from one in the hoopnet catch of 1940 are available for study. One of the two fish caught in nets in 1938 was spawned in 1935, and the ther belonged to a brood that was spawned in 1936. The one yellow bass taken in a net in $19+0$ also belonged to the 1936 brood. Calculated total lengths of yellow bass from Onized Lake are shown in table 27.

Table 27 indicates that the growth rate of yellow bass in Onized Lake was uniform. Stocking records show that fish were put in Onized Lake in 1934 and 1935, and a few yellow bass may have been spawned in the lake in 1936 . There is no evidence of a successful spawn since that date. In a study of the fish populations of 22 artificial lakes (Bennett 1943), yellow bass were present in 7 , including Onized Lake, but young fish of this species were found in only 1 , indicating that the yellow bass is unable to maintain its numbers in most small waters in Illinois.

The growth of yellow bass in Onized Lake was slow during the first season, very rapid during the second and less rapid in subsequent seasons; as increase in length represented a progressively greater increase in weight of these fish.

\section{Bullheads}

Ameiurus mclas mclas (Rafinesque)

Ameiurus natalis natalis (Le Sueur)

Only two black bullheads were taken in the final census of the fish of Onized Lake; one of these was a small fish of 0.56 pound and the other weighed 2.21 pounds. In the hoopnet catches of 1938 and 1940, one black bullhead was recorded for each season. Each of these fish weighed 2 pounds (or perhaps the same fish may have been caught in each year).

In recording the hook-and-line catch, no distinction was made between black and yellow bullheads. A total of 89 bullheads were caught, weighing 63.4 pounds, table 5. These represented 2.2 per cent of the number and 5.5 per cent of the weight of all fish caught. In view of the apparent scarcity of black bullheads, it is probable that nearly all of these fish were yellow bullheads.

In the final census of $19+1,3+7$ yellow bullheads were collected, table 7 . Age determinations on bullheads can be made by studying sections of bones and spines, but the process is so slow as to be impracticable in handling a large number of fish. When the numbers of bullheads of various lengths were tallied, all of the fish fell into three general length groups: the smallest from 4 to 7 inches, the next from $81 / 2$ to $101 / 2$ inches and the largest from 12 to $1+$ inches. As these groups were distinct, 
Table 28.-Hypothetical age-length distribution of the 347 yellow bullheads collected from Onized Lake in the census of June 24-28, 1941. Ages have been assigned on the basis of length. The census was made about $11 / 2$ months after the spawning season, and the lengths shown for each age include the growth increment for the early part of the 1941 season.

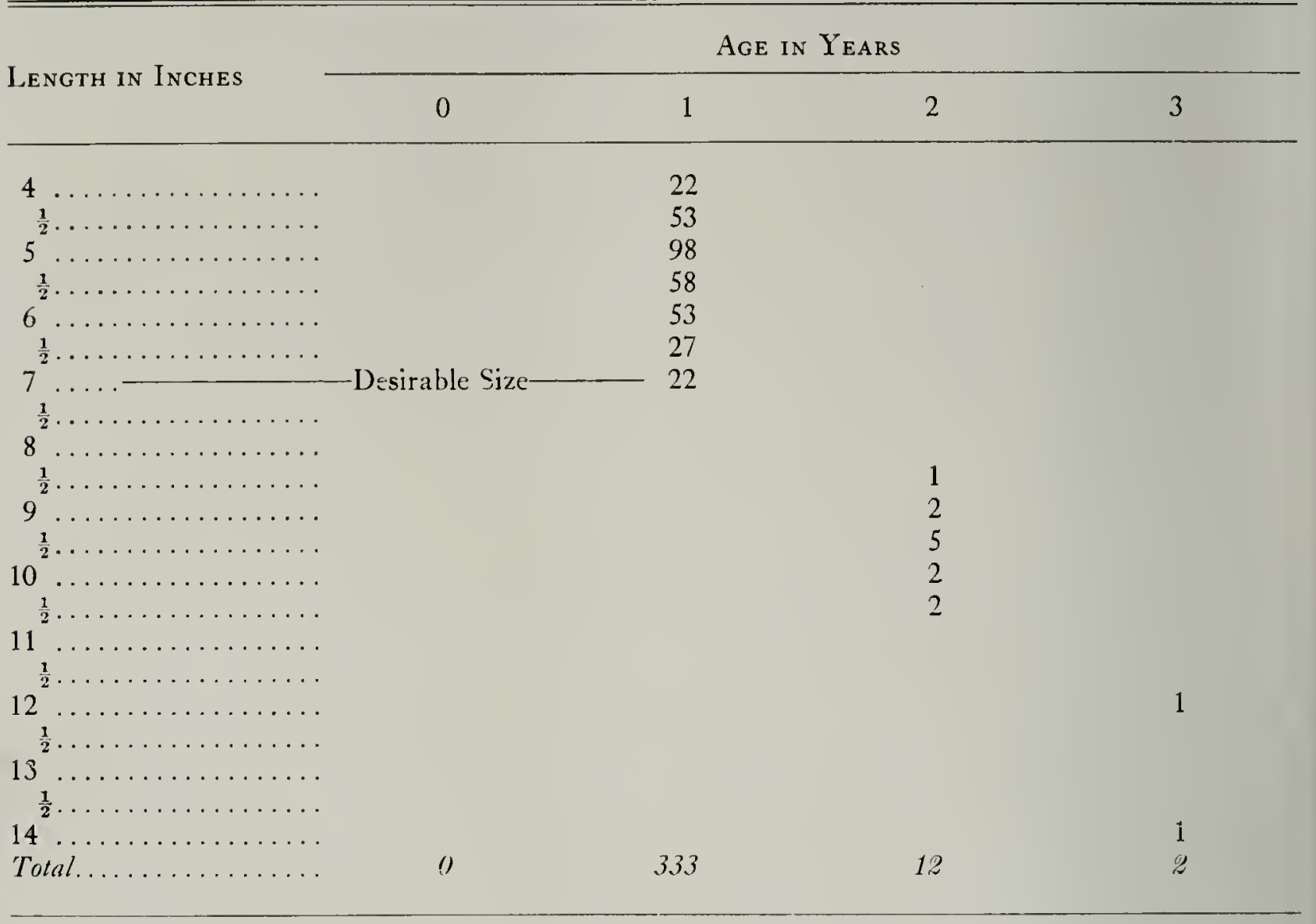

they suggest three age groups. Young bullheads are spawned during May in Onized Lake, and it is unlikely that any of the 4-inch fish taken in the census belonged to the brood of the 1941 season. Therefore, it is assumed that the 4- to 7inch group represented the 1940 brood; the $81 / 2$ - to $101 / 2$-inch group the 1939 brood; and the 12- to 14-inch group the 1938 brood (possibly the 14-inch fish belonged to the 1937 brood, although this seems unlikely, as bullheads are readily caught). The assumption of these various age groups has a validity it would not possess if the ranges of length in this species had overlapped.

Table 28 shows the age-length frequencies of yellow bullheads, sorted according to their hypothetical ages determined on the basis of their lengths.

Onized Lake is probably a poor habitat for bullheads, because of the steep slope of its basin and its limited shoal water. These characteristics, coupled with the complete absence of oxygen in the deeper waters in summer, result in a limited habi- tat for bottom-living species such as the black and yellow bullheads.

\section{Golden Shiner}

Notemigonus crysoleucas auratus (Rafinesque)

Golden shiners are not usually considered hook-and-line fish, but Onized Lake fishermen caught and kept them in 1940 and 1941. Certainly, desirable sizes of these fish cannot be less than 7 inches. The creel census records show 40 golden shiners, weighing a total of 7.7 pounds, table 5. In the 1941 final census, 90 shiners were collected, of which 37 were 7 or more inches long, tables 7 and 8 . The age-length distribution is given in table 29. This table shows that these golden shiners in Onized Lake made rapid growth and reached comparatively large sizes for minnows. Only fishermen and the larger bass could utilize the larger shiners.

Calculated lengths based on scale measurements of 87 golden shiners are given in table 30. These lengths are plotted as a growth curve in fig. 10 . 
Table 29.-Age-length frequencies of the 90 golden shiners collected from Onized Lake in the census of June $24-28,1941$. The census was made about $1 \frac{1}{2}$ months after the spawning season, and the lengths shown for each age include the growth increment for the early part of the 1941 season.

Age in lears

LENGTH IN INCHES

\begin{tabular}{cccc}
\multicolumn{5}{c}{ AgE IN YEARS } & \\
\hline 0 & 1 & 2 & 3
\end{tabular}

1
2 $\ldots \ldots \ldots \ldots \ldots \ldots \ldots$

$4 \ldots \ldots \ldots \ldots \ldots$

$\frac{1}{2} \ldots \ldots \ldots \ldots \ldots \ldots$

$5 \ldots \ldots \ldots \ldots \ldots \ldots$

$\frac{1}{2} \ldots \ldots \ldots \ldots \ldots \ldots$

$\sigma^{2} \ldots \ldots \ldots \ldots \ldots \ldots \ldots \ldots \ldots \ldots$

$\frac{1}{2} \ldots \ldots \ldots \ldots \ldots$

$7 \ldots \ldots \ldots \ldots \ldots$

$\frac{1}{2} \ldots \ldots \ldots \ldots \ldots \ldots$

$8 \ldots \ldots \ldots \ldots \ldots$

$\frac{1}{2} \ldots \ldots \ldots \ldots \ldots \ldots$

$9 \ldots \ldots \ldots \ldots \ldots \ldots$

Total.............

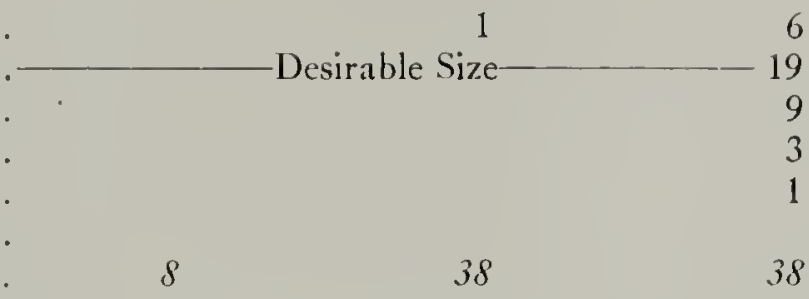

Table 30.-Average calculated total lengths in inches of 87 golden shiners collected from Onized Lake in the census of June 24-28, 1941.

\begin{tabular}{|c|c|c|c|c|c|}
\hline \multirow{2}{*}{ BROOD } & \multirow{2}{*}{$\begin{array}{c}\text { Number } \\
\text { of } \\
\text { Fish }\end{array}$} & AvERAGE & $\begin{array}{l}\text { Calculated Length } \\
\text { Years of IIfe }\end{array}$ & IS $B Y$ & \multirow{2}{*}{$\begin{array}{r}\text { Average Total } \\
\text { Length at Time } \\
\text { of Collection }\end{array}$} \\
\hline & & 1 & 2 & 3 & \\
\hline 1938. & 5 & 2.76 & 6.28 & 7.51 & 7.76 \\
\hline 1939. & 36 & 4.24 & 6.82 & & 7.19 \\
\hline 1940. & 38 & 3.31 & & & 5.25 \\
\hline 1941. & 8 & & & & 2.20 \\
\hline Total...... & 87 & & & & \\
\hline Average.... & & 3.70 & 6.75 & 7.51 & \\
\hline
\end{tabular}

Table 31.-Size frequencies for each group of female golden shiners taken from the Huron River at Ypsilanti, Michigan, May 19, 1934 (from Cooper 1935, rearranged).

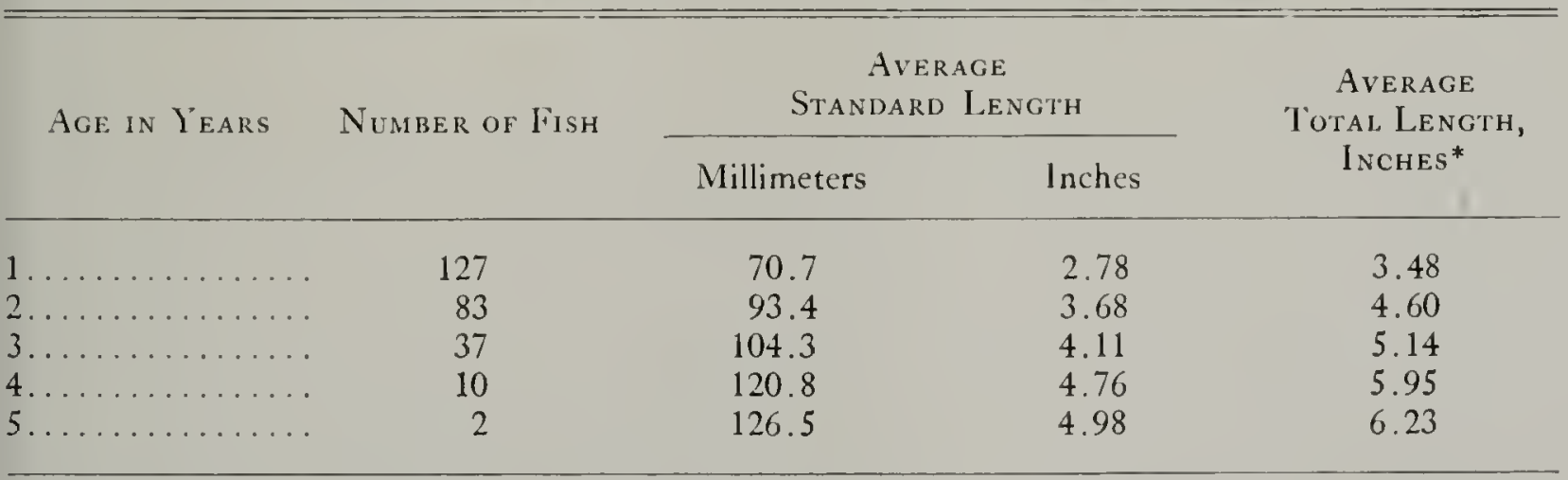

*Standard length converted to total length by the formula $\frac{\text { T.L. }}{\text { S.L. }}=1.25$. The formula is based on measurements of Hllinois golden shiners. 


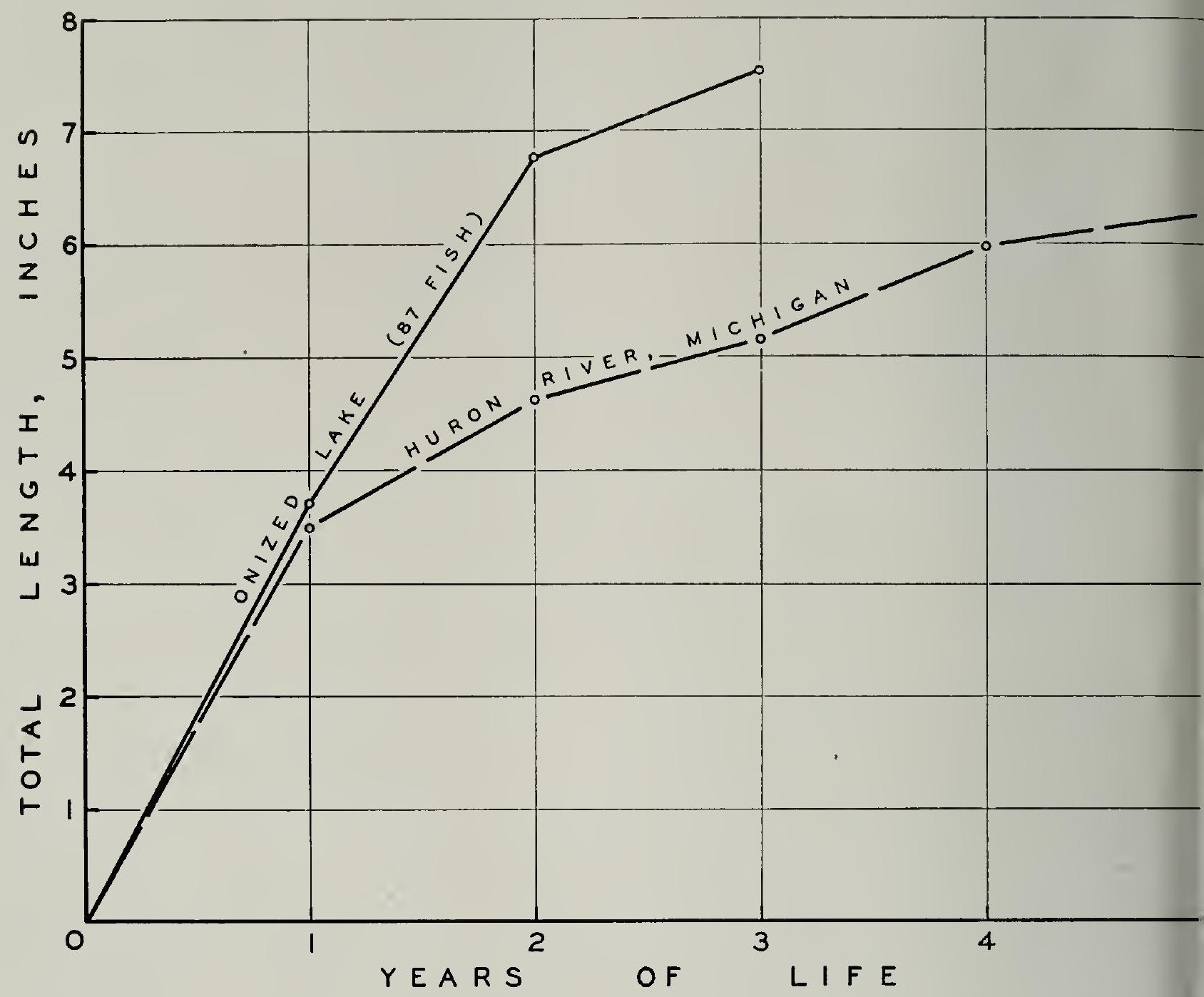

Fig. 10.-Average rate of growth of golden shiners in Onized Lake and in the Huron Rive. at Ypsilanti, Michigan.

Also in fig. 10 is shown a second curve based on female golden shiners collected and aged by Cooper (1936). These fish were taken from the Huron River at Ypsilanti, Michigan, May 19, 1934. Cooper's data, summarized in table 31 , offer evidence that the females of golden shiners live to a greater age and grow somewhat faster than males, and suggest that females predominated among the larger shiners in Onized Lake.

In Onized Lake, the first-year growth rate was essentially the same as in the Michigan collection of Cooper. However, Onized Lake shiners continued to grow at a rapid rate during the second year, while the rate of growth of the Michigan fish was much slower. Probably because of competition with other young fish, Onized Lake shiners grew less rapidly in their first year than might normally be expected in the southern part of Illinois.

The origin of the Onized Lake golden shiners is unknown. Possibly they wer stocked as forage for bass. Or they ma represent escaped bait.

\section{Miscellaneous Fish}

One carp, one common sucker and on blunt-nosed minnow were taken in th 1941 census.

This miscellaneous assortment of roug and forage fish probably represents bai that escaped the hooks of fishermel Onized Lake is some distance from othe water containing a variety of fish, and is improbable that these fish were carrie to the lake by fish-eating birds.

\section{Age Distribution of Fish}

The overfished population of Onize Lake was of particular interest from th standpoint of its age composition. As ina be seen from table 32 , overfishing tende to limit the life span of the fishes to tl 
Table 32.-Age composition of the fish population of Onized Lake; census of June 24-28, 1941.

\begin{tabular}{|c|c|c|c|c|c|c|c|}
\hline \multirow{2}{*}{ PECIES } & \multicolumn{6}{|c|}{ AgE IN YEARS } & \multirow[b]{2}{*}{ TOTAL } \\
\hline & 0 & 1 & 2 & 3 & 4 & 5 & \\
\hline Largemouth bass. & 33 & 195 & 24 & 8 & 7 & 8 & 275 \\
\hline Black crappie............. & & 15 & 7 & & & & 22 \\
\hline Bluegill . . . . . . . . . . . . . & 236 & 3,369 & 2,857 & 83 & & & 6,545 \\
\hline Warmouth bass . . . . . . . . . & & 1,165 & 466 & 7 & & & 1,638 \\
\hline Green sunfish . . . . . . . . . & & 187 & 49 & 8 & 1 & & 245 \\
\hline Yellow bass.............. & & & & & & 4 & 4 \\
\hline Black bullhead. .......... & & & 1 & 1 & & & 2 \\
\hline Yellow bullhead............ & & 333 & 12 & 2 & & & 347 \\
\hline Carp................. & & & & & 1 & & 1 \\
\hline Common sucker. . . . . . . . . & & 1 & & & & & 1 \\
\hline Golden shiner. . . . . . . . . . & 8 & 38 & 38 & 6 & & & 90 \\
\hline Blunt-nosed minnow. ....... & & 1 & & & & & 1 \\
\hline Total................. & 277 & 5,307 & 3,454 & 115 & 9 & 12 & 9,171 \\
\hline
\end{tabular}

approximate length of time that was required for them to reach desirable sizes. These sizes were attained by most species during the latter part of the second growing season. Some fish escaped being caught during the third season, but only a few remained to begin the fourth or fifth. Of these, the largemouth bass is the most notable and its survival is believed to hinge upon the probability that, of all species represented, it is the most wary and best able to learn from experience. Moreover, the life span of the largemouth is normally somewhat longer than that of other Illinois lake fishes.

Lines representing a pyramid of numbers of Onized Lake fish have been superimposed upon lines representing a similar pyramid for a theoretical fish population (Bennett 1943), fig. 11. This figure

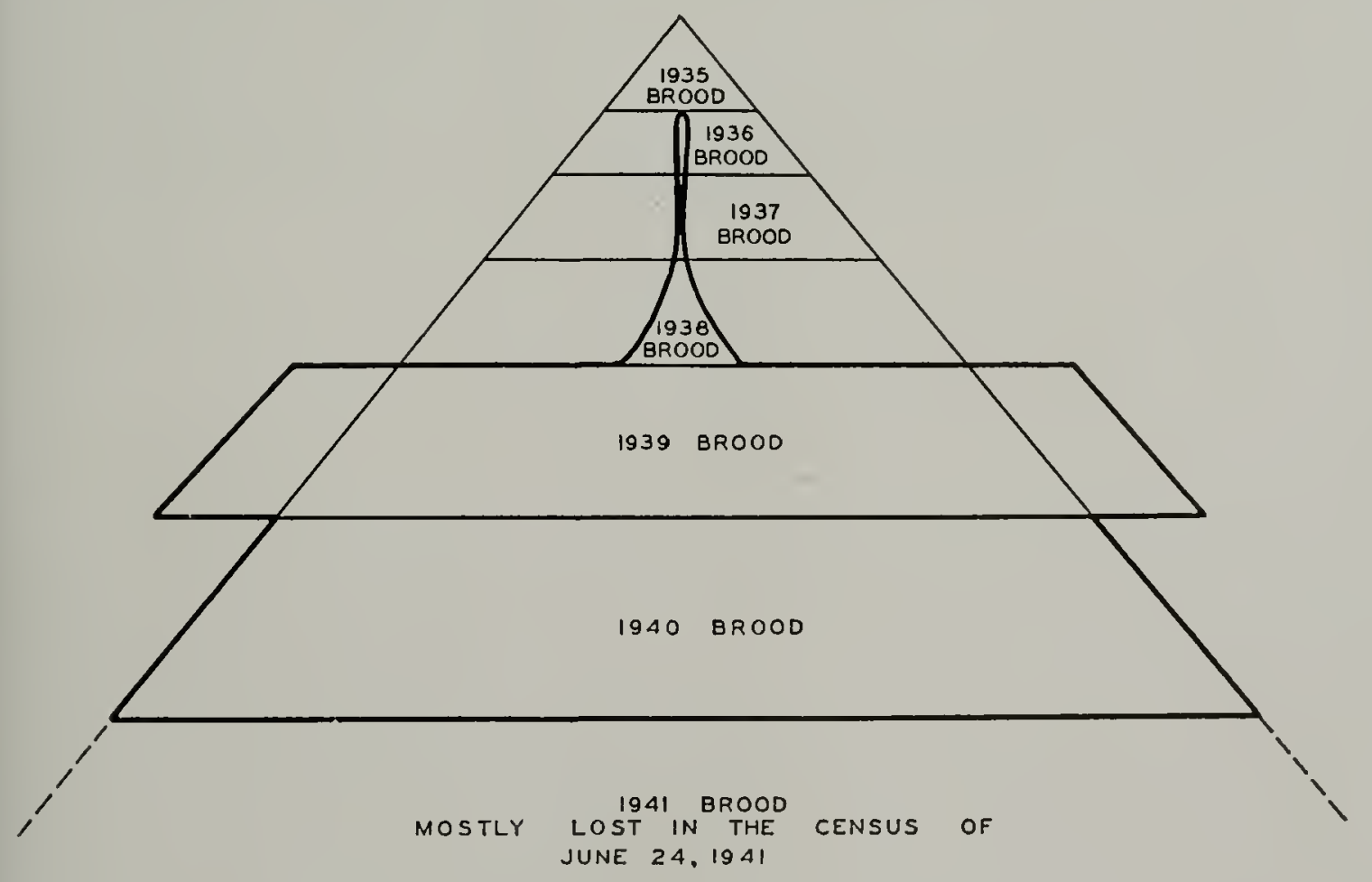

Fig. 11.-Diagram representing the age-frequency distribution of Onized lake fish, final 1941 census, superimposed upon a pyramid of numbers representing a theoretical fish population. This diagram suggests that overfishing tends to remove most of the older and larger fish, but has little effect upon the production of adequate broods of young. 
illustrates the tendency of overfishing to remove the larger and older fish. The 1941 census was made shortly after completion of the 1941 spawn, and, as the $19+1$ brood was composed of very small fish, most of which were lost in the census, this brood is represented as the pyramidal base enclosed in dotted lines. When quadrilaterals representing the 1940 and 1939 broods are superimposed upon the theoretical pyramid, with the lines for the 1940 brood coinciding with the limits of the theoretical quadrilateral for 1940 , the lines for the 1939 brood extend beyond the limits of the theoretical quadrilateral for the corresponding year. The figure representing the 1938 brood shows that this brood was only a small fraction of the size of the 1939 brood and much smaller than the theoretical quadrilateral for 1938; the effects of overfishing are thus indicated. Older broods are represented by a spearhead extending toward the apex of the theoretical pyramid.

\section{Discussion}

All sources of evidence point to the hypothesis that Onized Lake was severely overfished. Yet every species of fish known to be once numerous in the lake was present in the final census, perhaps due to the fact that fishing pressure drew its quota from all kinds of fish present, rather than from one or two of the more desirable species. The many fishermen using the lake represented a cross section of anglers, their fishing gear running the gamut from willow-pole to flyrod. The fish in this lake were presented with a variety of baits and hook sizes, attractive to all but the smallest.

It is possible that if the fishing intensity had been directed toward a certain species, to the exclusion of others, that species might have been entirely eliminated. This could be expected to occur, not directly through intensive fishing, but indirectly through the inability of reduced numbers of spawn or young of the selected species (because of fewer breeding adults) to compete with the more numerous young and adults of other species not affected by fishing. For all practical purposes, the lake would have become "fished out" for the selected species before all of the adults had been caught, but it is rather unlikely that the few remaining could have produced enough young to compete with young of the more numerous species. In the 1941 census, the black bullheads and yellow bass were only a few in number, but in view of the fact that the hook-andline catch was made up of only small numbers of yellow bass and bullheads, and the hoopnet collections of 1938 failed to indicate abundant populations of these fish, the conclusion must be reached that some factors other than heavy fishing kept them from becoming numerous.

The black crappies of Onized Lake were nearer extermination than any other species known to be numerous in the past. However, the creel census does not indicate that particularly large catches of these fish were made, fig. 5. Only during 1939 were appreciable numbers taken. In that year the crappie catch ranked second to the bluegill in numbers and well ahead of any other species. In 1940, the total hook-andline catch of crappies was only 56 ; yet hoopnets set during July of that year caught 234 black crappies, more than twice the number of bluegills and many times the numbers of other fish caught, table 6 . The fact that only 56 crappies were taken by anglers in 1940, and 31 in 1941, following a catch of 502 in 1939, suggests a natural die-off of the older fish during the latter half of the summer of 1940 . The only other evidence for the natural die-off assumption is that large numbers of crappies were not present in the final census.

All species of fish in Onized Lake from which scales were studied showed poor growth during the first season, and all but one, the warmouth bass, grew at an exceptionally rapid rate throughout later years of life. This situation can be explained by assuming that the constant drain on the adult fish population through heavy fishing allowed increased success in spawning and greater survival of young fish. Thus, foods suitable for small fish were at a premium, and early growth was slow. However, once the young fish reached sizes large enough to allow them to feed upon larger food organisms, they grew rapidly, because the constant take of adults eased the food competition in this size range.

The fishing intensity at Onized Lake during the period of this study was so great that most of the fish were caught before they reached the age of 3 years; a 
of 1939 and 1940, and April, May and June of 1941. The fishing intensity was light in 1938 (end of the season), but for the 1939 season it was $1,414.9$ man-hours per acre; for 1940, 1,647.3 man-hours per acre; and, for April, May and June of $1941,634.0$ man-hours per acre. Hookand-line fish yields were, for 1939, 349.95 pounds per acre; for $1940,142.5$ pounds per acre; and, for 3 months of 1941, 70.9 pounds per acre. Hoopnet sampling of August 28-30, 1938, compared with catches made with nets July 10-15, 1940, indicated a reduction in the population of large-sized fish between these two sampling periods.

3. A poison census was made on June 24,1941 . At this time the lake contained 9,171 fish weighing 442.17 pounds. The kinds of fish present were largemouth bass, black crappies, bluegills, warmouth bass, green sunfish, yellow bass, black bullheads, yellow bullheads and golden shin- ers, as well as one carp, one common sucker and one blunt-nosed minnow.

4. Fish were relatively stunted during the first year of life, but most species grew at an exceptionally rapid rate during later years. The ôldest fish were in their sixth summer of life, and nearly all of these. were largemouth bass. Most of the fish were taken when in their third summer.

5. A large population of black crappies had been reduced to 22 fish by the time of the final census. This reduction was apparently not due to hook-and-line fishing. Largemouth bass and bluegills remained numerous, although they had made up an important part of the hook-and-line catch.

6. In spite of heavy fishing, the natural spawn of fish was obviously sufficient to insure replacement of those fish removed, and under reduced fishing intensity the lake would have returned to its former carrying capacity.

\section{LITERATURE CITED}

\section{Beckman, William C.}

1941. Increased growth rate of rock bass, Ambloplites rupestris (Rafinesque), following reduction in density of the population. Am. Fish. Soc. Trans. 70:143-8.

Bennett, George W.

1937. The growth of the large mouthed black bass, Huro salmoides (Lacépède), in the waters of Wisconsin. Cope. $1937(2): 104-18$. 6 figs.

1943. Management of small artificial lakes, a summary of fisheries investigations, 1938-1942. I1l. Nat. Hist. Surv. Bul. 22(3) :357-76. 7 figs.

Bennett, George W., David H. Thompson and Sam A. Parr

1940. Lake management reports. 4. A second year of fisheries investigations at Fork Lake, 1939. IIl. Nat. Hist. Surv. Biol. Notes 14. 24 pp., 10 figs., 4 pls.

Cooper, Gerald P.

1936. Age and growth of the golden shiner (Notcmigonus crysoleucas auratus) and its suitability for propagation. Mich. Acad. Sci., Arts and Letters Papers 21:587-97. 3 figs.

Eschmeyer, R. W., and Alden M. Jones

1941. The growth of game fishes in Norris Reservoir during the first five years of impoundment. N. Am. Wildlife Conf. Trans. 6, $1941: 222-40.4$ figs.

Hubbs, Carl L., and Gerald P. Cooper

1935. Age and growth of the long-eared and green sunfishes in Michigan. Mich. Acad. Sci., Arts and Letters Papers $20: 669-96.5$ pls.

Schloemer, Clarence Louis

1939. The age and rate of growth of the bluegill, Helioperca macrochira (Rafinesque). Doctoral Dissertation, University of Wisconsin.

Schoffman, Robert J.

1940. Age and growth of the black and white crappie, the warmouth bass, and the yellow bass in Reelfoot Lake. Reelfoot Lake Biol. Sta. Rpt. 4:22-42. 9 figs.

Swingle, H. S., and E. V. Smith

1943. Factors affecting the reproduction of bluegill, bream and largemouth black bass in ponds. Ala. Ag. Exp. Sta. Circ. 87:1-8.

Thompson, David H., and George W. Bennett

1939. Lake management reports. 3. Lincoln Lakes near Lincoln, Illinois. Ill. Nat. Hist. Surv. Biol. Notes 11. 24 pp., 8 figs. 




\section{Recent Publications}

A.-ILLINOIS NATURAL HISTORY SURVEY BULLETIN.

Volume 21, Article 3.-Studies of Nearctic Aquatic Insects. By H. H. Ross and T. H Frison. September, 1937. 52 pp., frontis. +86 figs., bibliog. 50 cents.

Volume 21, Article 4.-Descriptions of Nearctic Caddis Flies (Trichoptera), with special reference to the Illinois species. By Herbert H. Ross. March, 1938. 84 pp., frontis. +123 figs., foreword, index. $\$ 1.00$.

Volume 21, Article 5.-Preliminary Studies on Parasites of Upland Game Birds and Fur-Bearing Mammals in Illinois. By W. Henry Leigh. August, 1940. 10 pp., frontis. +2 maps.

Volume 21, Article 6.-Preliminary Investigation of Oak Diseases in Illinois. By J. Cedric Carter. June, 1941. 36 pp., frontis. + 51 figs., bibliog. (Bound with Article 7.)

Volume 21, Article 7.-A Needle Blight of Austrian Pine. By Robert L. Hulbary. June, 1941. 6 pp., frontis. +3 figs., bibliog. (Bound with Article 6.)

Volume 21, Article 8.-Duck Food Plants of the Illinois River Valley. By Frank C. Bellrose, Jr. August, 1941. 44 pp., frontis. + 35 figs., bibliog., appendix.

Volume 22, Article 1.-The Plant Bugs, or Miridae, of Illinois. By Harry H. Knight. September, 1941. 234 pp., frontis. +181 figs., bibliog., index. $\$ 1.25$.

Volume 22, Article 2.- Studies of North American Plecoptera, with special reference to the fauna of Illinois. By T. H. Frison. September, 1942. 122 pp., frontis. +126 figs., bibliog., index. $\$ 1.00$.

Volume 22, Article 3.-Management of Small Artificial Lakes: a summary of fisheries investigations, 1938-1942. By George W. Bennett. February, 1943. 20 pp., frontis. +7 figs., bibliog.

Volume 22, Article 4.-The Prairie Chicken in Illinois. By Ralph E. Yeatter. May, 1943. 40 pp., frontis. +18 figs., bibliog. (Bound with Article 5.)

Volume 22, Article 5.- Preferential Rating of Duck Food Plants. By Frank C. Bellrose, Jr., and Harry G. Anderson. May, 1943. 16 pp., frontis. + 16 figs., bibliog. (Bound with Article 4.)

Volume 22, Article 6.-Survey of the Illinois Fur Resource. By Louis G. Brown and Lee E. Yeager. September, 1943. 70 pp., frontis. +33 figs., bibliog. (Bound with Article 7.)

Volume 22, Article 7.--Illinois Furbearer Distribution and Income. By Carl O. Mohr. September, 1943. 33 pp., frontis. + 24 figs., bibliog. (Bound with Article 6.)

Volume 23, Article 1. - The Caddis Flies, or Trichoptera, of Illinois. By Herbert $H$. Ross. August, 1944. 326 pp., frontis. + 961 figs., bibliog., index. $\$ 1.50$.

Volume 23, Article 2.-Duck Populations and Kill. By Frank C. Bellrose, Jr. November, 1944. 46 pp., frontis. +27 figs., bibliog.

\section{B.-ILLINOIS NATURAL HISTORY SURVEY CIRCULAR.}

32.-Pleasure With Plants. By L. R. Tehon. November, 1942. (Second printing, with revisions.) 32 pp., frontis. +9 figs.

33. - Controlling Peach Insects in Illinois. By S. C. Chandler and W. P. Flint. August, 1939. 40 pp., frontis. + 32 figs.

34.- Rout the Weeds! Why, When and How. By L. R. Tehon. August, 1943. (Third printing.) $47 \mathrm{pp}$., color frontis. +13 figs.

35.-Diseases of Small Grain Crops in Illinois. By G. H. Boewe. September, 1939. 130 pp., frontis. +47 figs.

36. - Planting and Care of Shade Trees. By J. E. Davis. March, 1941. 23 pp., frontis. +16 figs.

37. - Outwitting Termites in Illinois. By W. E. McCauley and W. P. Flint. August 1942. (Second printing.) 23 pp., frontis. +19 figs.

38. - Windbreaks for Illinois Farmsteads. By J. E. Davis. February, 1942. (Second printing.) 24 pp., frontis. + 19 figs.

39.-How to Collect and Preserve Insects. By H. H. Ross. May, 1944. (Second printing, with additions.) 55 pp., frontis. +63 figs.

40.-Control of Roundheaded Apple Tree Borer. By S. C. Chandler and W. P. Flint. April, 1942. 8 pp., 6 figs.

\section{C.-ILLINOIS NATURAL HISTORY SURVEY MANUAL.}

1.-Fieldbook of Illinois Wild Flowers. By the staff. March, 1936. $406 \mathrm{pp}$, color frontis. + 349 figs., index. $\$ 1.50$.

2.-Fieldbook of Illinois Land Snails. By Frank Collins Baker. August, 1939. 166 pp. color frontis. +170 figs., 8 pls. $\$ 1.00$.

3.-Fieldbook of Native Illinois Shrubs. By Leo R. Tehon. December, 1942. 307 pp. 4 color pls. +72 figs., glossary, index. $\$ 1.25$.

List of available prublications, about 400 titles, mailed on request.

Address orders and correspondence to the Chief

ILliNOIS NATURAX HISTORY SURVEY

Natural Resources Building, Urbana, Illinois

Paymert in the form of U. S. Poat Office voney order made out to

State Treasurer of Illinois, Springfield, Illinois,

must accompany requests for those publications on which a price is set. 